\title{
Evolution of the Latir Volcanic Field, Northern New Mexico, and Its Relation to the Rio Grande Rift, as Indicated by Potassium-Argon and Fission Track Dating
}

\author{
Peter W. Lipman, Harald H. Mehnert, and Charles W. Naeser
}

\author{
U.S. Geological Survey, Denver, Colorado
}

\begin{abstract}
Remnants of the Latir volcanic field and cogenetic plutonic rocks are exceptionally exposed along the east margin of the present-day Rio Grande rift by topographic and structural relief in the Sangre de Cristo Mountains of northern New Mexico. Evolution of the magmatic system associated with the Latir field, which culminated in eruption of a regional ash flow sheet (the Amalia Tuff) and collapse of the Questa caldera $26 \mathrm{~m}$.y. ago, has been documented by 74 new potassium-argon (K-Ar) and fission track (F-T) ages. The bulk of the precaldera volcanism, ash flow eruptions and caldera formation, and initial crystallization of the associated shallow granitic batholith took place between 28 and $25 \mathrm{Ma}$; economically important molybdenum mineralization is related to smaller granitic intrusions along the south margin of the Questa caldera at about $23 \mathrm{Ma}$. Interpretation of the radiogenic ages within this relatively restricted time span is complicated by widespread thermal resetting of earlier parts of the igneous sequence by later intrusions. Many samples yielded discordant ages for different mineral phases. Thermal blocking temperatures decrease in the order: K-Ar sanidine $>\mathrm{K}$-Ar biotite $>$ F-T zircon $\gg$ F-T apatite. The F-T results are especially useful indicators of cooling and uplift rates. Upper portions of the subvolcanic batholith, that underlay the Questa caldera, cooled to about $100^{\circ} \mathrm{C}$ within about a million years of emplacement; uplift of the batholith increases to the south along this segment of the Sangre de Cristo Mountains. Activity in the Latir volcanic field was concurrent with southwest directed extension along the early Rio Grande rift zone in northern New Mexico and southern Colorado. The geometry of this early rifting is compatible with interpretation as back arc extension related to a subduction system dipping gently beneath the cordilleran region of the American plate. The Latir field lies at the southern end of a southward migrating Tertiary magmatic locus, along which much of the southern Rocky Mountains was blanketed by volcanic rocks in Eocene and Oligocene time. This southward migration of igneous activity through the Rocky Mountains may have been a critical precursor that, by heating and weakening the lithosphere, helped localize initial extensional deformation in the eastern Cordilleran region. Ages of rift-related basaltic volcanism in the Questa-Latir area span an apparent magma gap 20-10 m.y. ago, inferred by others for more southern sectors of the Rio Grande rift. Rift-related volcanism was nearly continuous through Miocene and Pliocene time in the northern New Mexico sector of the rift, perhaps because of intersection with the diffuse northeast trending Jemez magmatic zone.
\end{abstract}

\section{INTRODUCTION}

The Latir volcanic field, along with the associated Questa caldera, constitutes the largest mid-Tertiary volcanic system in northern New Mexico. This volcanic terrane is interpreted as the surface manifestation of shallow crustal accumulation and evolution of a large shallow magma body (the Questa magmatic system) that was active during early development of the Rio Grande rift zone in latest Oligocene and early Miocene time. Seventy-four new K-Ar and fission track (F-T) ages on igneous rocks of the Latir field, along with previously published ages, are used here to document the history of the volcanic field, its association with molybdenum mineralization, structural relations to the Rio Grande rift, and some interpretative problems with geochronologic data from deeper parts of volcanic systems. This work is based on mapping of the volcanic field and associated intrusive rocks between 1979 and 1983; preliminary summaries of the igneous geology and a geologic map of part of the area have been published [Lipman, 1983; Reed et al., 1983].

Igneous rocks of the Latir field were dated by conventional K-Ar and F-T techniques (Tables 1 and 2); where possible, multiple determinations were made on different mineral phases from the same sample. Mineral separations were all at least $95 \%$ pure; variable oxidation of some biotites from in-

This paper is not subject to U.S. copyright. Published in 1986 by the American Geophysical Union.

Paper number 5B5448. trusions is reflected by low potassium contents. Argon determinations were by isotope dilution, using enriched ${ }^{38} \mathrm{Ar}$ spikes; potassium was determined by flame photometer. Fission track determinations were by techniques summarized by Naeser [1979]. Such methods, which have repeatedly yielded reliable results on fresh volcanic rocks that have not been deeply buried or significantly heated, are more difficult to apply to deeply eroded volcanic areas such as the Latir field. In this environment, thermal conditions caused by deep burial of volcanic strata, by proximity to younger intrusions and mineralizing fluids, and by variable rates of uplift during later Cenozoic extensional deformation have combined to yield complex radiogenic age results.

Interpretations of igneous events and geologic history of deep volcanic environments, based on only a few geochronologic results, are fraught with uncertainty. For example, prior to the present study, sparse published ages for the LatirQuesta area could be interpreted to suggest, erroneously, that the major regional ash flow sheet of the Latir field (the Amalia Tuff) was erupted at about 22-23 Ma [Pillmore et al., 1973], concurrently with emplacement of the granitic rocks associated with mineralization in the same area [Laughlin et al., 1969]. In contrast, our results show that the Amalia Tuff was erupted 3-4 Ma prior to intrusion of the mineralized granite and that published ages on the tuff reflect thermal resetting of the $\mathrm{K}$-Ar system by the later intrusive activity. Fission tracks in zircon have proved to be subject to annealing in the thermal environment adjacent to the Questa caldera; as a result, our interpretations of evolution of the 
Latir field have been based primarily on the K-Ar data. The F-T results, which tend to yield postemplacement "ages," have proved especially useful in inferring the thermal history and rates of uplift of this segment of the Sangre de Cristo Mountains.

\section{Regional Setting}

The Latir volcanic field and associated intrusive rocks constitute a previously little-studied Tertiary igneous complex in the Sangre de Cristo Mountains of northern New Mexico (Figure 1), near the southeastern margin of the large composite Tertiary volcanic field of the southern Rocky Mountains [Steven, 1975]. Erosional remnants of the Latir field presently extend over an area of about $1200 \mathrm{~km}^{2}$; facies relations among the preserved volcanic rocks indicate that the Latir field originally covered a much larger part of the Sangre de Cristo Mountains. In addition to complex internal disruption by late Tertiary extensional faulting, the Latir field is truncated along its west side by the present Rio Grande rift zone. Fragmentary exposures of penecontemporaneous volcanic rocks along a horst within the rift [Lipman and Mehnert, 1979; Thompson and Dungan, 1984] and widespread volcaniclastic sedimentary accumulations in the Brazos (Tusas) Mountains west of the rift [Butler, 1971; Manley, 1981] indicate that rocks of the Latir field extend far west of the Sangre de Cristo Mountains and originally merged with outflow facies from the San Juan volcanic field to the northwest.

Rock of the Latir field are preserved mostly within and north of the Questa caldera; cogenetic plutonic rocks have been exposed by deeper erosion to the south (Figure 2). This geometry indicates that regional post-Miocene uplift of the Taos sector of the Sangre de Cristo Mountains was at least 2 $\mathrm{km}$ greater in the south than in the north. At the northern margin of the study area, near the town of Amalia (Figure 2), the Latir volcanic sequence disappears below alluvium in the Rio Grande rift at elevations of about $2000 \mathrm{~m}$. At the southern

TABLE 1. New Potassium-Argon Analytical Data, Tertiary Rocks of the Latir Volcanic Field, Northern New Mexico

\begin{tabular}{|c|c|c|c|c|c|c|c|c|c|}
\hline \multirow[b]{2}{*}{$\begin{array}{l}\text { Sam- } \\
\text { ple" }\end{array}$} & \multirow[b]{2}{*}{$\begin{array}{c}\text { DKA } \\
\text { Lab }\end{array}$} & \multirow[b]{2}{*}{ Field } & \multicolumn{2}{|c|}{ Location } & \multirow[b]{2}{*}{$\begin{array}{c}\text { Rock } \\
\text { Type, } \\
\text { Mineral } \dagger\end{array}$} & \multirow[b]{2}{*}{$\underset{\%}{\mathbf{K}_{2} \mathbf{O}}$} & \multirow{2}{*}{$\begin{array}{l}{ }^{40} \mathrm{Ar}^{*}, \\
10^{-10} \\
\mathrm{~mol} / \mathrm{g}\end{array}$} & \multirow[b]{2}{*}{$\begin{array}{l}{ }^{40} \mathrm{Ar}^{*}, \\
\%\end{array}$} & \multirow[b]{2}{*}{ Age $\underset{\mathrm{Ma}}{ \pm} 2$ sd } \\
\hline & & & $\underset{{ }^{\circ} \mathbf{N}}{\text { Latitude, }}$ & $\begin{array}{l}\text { Longitude, } \\
{ }^{\circ} \mathbf{W}\end{array}$ & & & & & \\
\hline \multicolumn{10}{|c|}{ Precaldera Rocks } \\
\hline 1 & 4190 & $79 \mathrm{~L}-62$ & $36^{\circ} 48.08^{\prime}$ & $105^{\circ} 18.07^{\prime}$ & Bio. & $5.29,5.27$ & 2.121 & 74.7 & $27.7 \pm 1.2$ \\
\hline & 4211 & $79 \mathrm{~L}-62$ & $36^{\circ} 48.08^{\prime}$ & $105^{\circ} 18.07^{\prime}$ & Hbl. & $1.26,1.27$ & 0.526 & 76.0 & $28.6 \pm 1.2$ \\
\hline \multirow[t]{2}{*}{2} & $\begin{array}{l}4655 \\
4738\end{array}$ & \multicolumn{2}{|c|}{ (replicate analysis) } & $105^{\circ} 26.80^{\prime}$ & Bio. & $8.11,8.09$ & 3.366 & 65.7 & $28.6 \pm 1.1$ \\
\hline & $\begin{array}{l}4656 \\
4737\end{array}$ & $83 \mathrm{~L}-12$ & $\begin{array}{c}36^{\circ} 51.90^{\prime} \\
\text { olicate analy }\end{array}$ & $\begin{array}{l}105^{\circ} 26.80^{\prime} \\
\text { sis) }\end{array}$ & Hbl. & $0.77,0.76$ & $\begin{array}{l}3.388 \\
0.317 \\
0.315\end{array}$ & $\begin{array}{l}68.6 \\
72.4 \\
65.0\end{array}$ & $\begin{array}{l}28.8 \pm 1.1 \\
28.5 \pm 1.3 \\
28.3 \pm 1.6\end{array}$ \\
\hline 4 & 3738 & $78 \mathrm{~L}-146$ & $36^{\circ} 46.40^{\prime}$ & $105^{\circ} 20.88^{\prime}$ & Hbl. & $0.92,0.92$ & 0.379 & 77.3 & $28.4 \pm 1.3$ \\
\hline 5 & 4734 & 83L-8 & $36^{\circ} 51.50^{\prime}$ & $105^{\circ} 26.80^{\prime}$ & Bio. & $8.40,8.36$ & 3.284 & 80.1 & $27.0 \pm 1.0$ \\
\hline & 4654 & $83 \mathrm{~L}-8$ & $36^{\circ} 51.50^{\prime}$ & $105^{\circ} 26.80^{\prime}$ & San. & $10.84,10.80$ & 4.027 & 82.0 & $25.7 \pm 0.9$ \\
\hline 6 & 3739 & $78 \mathrm{~L}-180$ & $36^{\circ} 51.83^{\prime}$ & $105^{\circ} 24.33^{\prime}$ & Plag. & $0.70,0.74$ & 0.214 & 66.1 & $20.5 \pm 1.0$ \\
\hline \multicolumn{10}{|c|}{ Amalia Tuff and Related Rocks } \\
\hline 8 & 4554 & $82 \mathrm{~L}-37$ & $36^{\circ} 45.93^{\prime}$ & $105^{\circ} 23.79^{\prime}$ & San. & $8.75,8.74$ & 3.459 & 50.4 & $27.3 \pm 1.2$ \\
\hline 9 & 4650 & $82 \mathrm{~L}-42 \mathrm{H}$ & $36^{\circ} 56.27^{\prime}$ & $105^{\circ} 13.31^{\prime}$ & San. & $7.45,7.40$ & 2.924 & 94.6 & $27.2 \pm 0.9$ \\
\hline 10 & 4651 & $82 \mathrm{~L}-42 \mathrm{D}$ & $36^{\circ} 56.17^{\prime}$ & $105^{\circ} 13.26^{\prime}$ & San. & $7.91,7.90$ & 2.975 & 87.0 & $26.0 \pm 0.9$ \\
\hline 11 & 4558 & $82 \mathrm{~L}-38$ & $36^{\circ} 28.79^{\prime}$ & $106^{\circ} 00.10^{\prime}$ & San. & $6.75,6.80$ & 2.584 & 77.0 & $26.3 \pm 1.0$ \\
\hline 13 & 3744 & $78 \mathrm{~L}-183$ & $36^{\circ} 50.41^{\prime}$ & $105^{\circ} 24.26^{\prime}$ & San. & $4.54,4.55$ & 1.802 & 83.7 & $27.9 \pm 1.0$ \\
\hline 14 & 4553 & $82 L-31$ & $36^{\circ} 50.32^{\prime}$ & $105^{\circ} 24.36^{\prime}$ & San. & $6.45,6.64$ & 2.245 & 73.2 & $23.7 \pm 1.1$ \\
\hline \multicolumn{10}{|c|}{ Intrusive Rocks: Northern Fault-Controlled Intrusions } \\
\hline 20 & 3731 & $78 \mathrm{~L}-181$ & $36^{\circ} 51.72^{\prime}$ & $105^{\circ} 24.25^{\prime}$ & Bio. & $7.11,7.48$ & 2.947 & 81.6 & $27.9 \pm 1.0$ \\
\hline & 3741 & $78 \mathrm{~L}-181$ & $36^{\circ} 51.72^{\prime}$ & $105^{\circ} 24.25^{\prime}$ & Plag. & 26 & 0.360 & 71.8 & $20.1 \pm 1.0$ \\
\hline \multirow[t]{2}{*}{21} & 4739 & $83 \mathrm{~L}-16$ & $36^{\circ} 51.80^{\prime}$ & $105^{\circ} 24.20^{\prime}$ & Bio. & $8.15,8.20$ & 3.236 & 72.6 & $27.3 \pm 1.0$ \\
\hline & 4657 & $83 \mathrm{~L}-16$ & $36^{\circ} 51.80^{\prime}$ & $105^{\circ} 24.20^{\prime}$ & Hbl. & $0.88,0.88$ & 0.329 & 56.8 & $25.8 \pm 1.1$ \\
\hline \multirow[t]{2}{*}{22} & 4192 & $79 \mathrm{~L}-64$ & $36^{\circ} 50.10^{\prime}$ & $105^{\circ} 18.88^{\prime}$ & Bio. & $8.30,8.35$ & 3.048 & 78.4 & $25.3 \pm 1.3$ \\
\hline & 4213 & $79 \mathrm{~L}-64$ & $36^{\circ} 50.10^{\prime}$ & $105^{\circ} 18.88^{\prime}$ & San. & $9.05,8.94$ & 3.198 & 90.3 & $24.5 \pm 1.0$ \\
\hline \multirow[t]{2}{*}{23} & 4191 & $79 \mathrm{~L}-65$ & $36^{\circ} 50.31^{\prime}$ & $105^{\circ} 18.46^{\prime}$ & Bio. & $6.52,6.69$ & 2.578 & 67.2 & $26.9 \pm 1.1$ \\
\hline & 4210 & $79 \mathrm{~L}-65$ & $36^{\circ} 50.31^{\prime}$ & $105^{\circ} 18.46^{\prime}$ & Hbl. & $1.58,1.56$ & 0.506 & 55.1 & $22.3 \pm 1.0$ \\
\hline \multirow[t]{2}{*}{24} & 4556 & $82 \mathrm{~L}-34$ & $36^{\circ} 50.30^{\prime}$ & $105^{\circ} 18.57^{\prime}$ & Bio. & $8.45,8.43$ & 3.417 & 76.1 & $27.9 \pm 1.0$ \\
\hline & 4552 & $82 \mathrm{~L}-34$ & $36^{\circ} 50.30^{\prime}$ & $105^{\circ} 18.57^{\prime}$ & Hbl. & $0.90,0.89$ & 0.373 & 53.6 & $28.7 \pm 1.3$ \\
\hline \multicolumn{10}{|c|}{ Intrusive Rocks: Intracaldera Plutons } \\
\hline 25 & 4344 & $80 \mathrm{~L}-27$ & $36^{\circ} 47.16^{\prime}$ & $105^{\circ} 30.20^{\prime}$ & $\mathbf{K F}$ & $7.73,7.71$ & 2.857 & 78.6 & $25.5 \pm 1.1$ \\
\hline 26 & 4345 & $80 \mathrm{~L}-52$ & $36^{\circ} 47.70^{\prime}$ & $105^{\circ} 32.28^{\prime}$ & KF & 7.27 & 2.617 & 68.3 & $24.5 \pm 1.1$ \\
\hline \multirow[t]{3}{*}{27} & 4557 & $82 \mathrm{~L}-35$ & $36^{\circ} 47.71^{\prime}$ & $105^{\circ} 32.16^{\prime}$ & KF & $8.47,8.51$ & 3.062 & 88.3 & $24.9 \pm 0.9$ \\
\hline & 4551 & $82 \mathrm{~L}-35$ & $36^{\circ} 47.71^{\prime}$ & $105^{\circ} 32.16^{\prime}$ & Bio. & $9.32,9.32$ & 3.413 & 64.2 & $25.3 \pm 1.0$ \\
\hline & 4559 & $82 \mathrm{~L}-35$ & $36^{\circ} 47.71^{\prime}$ & $105^{\circ} 32.16^{\prime}$ & Musc. & $10.00,10.08$ & 3.822 & 63.8 & $26.3 \pm 1.0$ \\
\hline 28 & 3729 & $78 \mathrm{~L}-172$ & $36^{\circ} 44.75^{\prime}$ & $105^{\circ} 30.39^{\prime}$ & KF & $6.52,6.51$ & 2.029 & 82.1 & $21.5 \pm 1.0$ \\
\hline & 3765 & $78 \mathrm{~L}-172$ & $36^{\circ} 44.75^{\prime}$ & $105^{\circ} 30.39^{\prime}$ & Bio. & $8.50,8.41$ & 3.019 & 80.7 & $24.6 \pm 0.9$ \\
\hline \multicolumn{10}{|c|}{ Intrusive Rocks: Southern Intrusions } \\
\hline 32 & 4343 & $80 \mathrm{~L} \sim 6 \mathrm{~A}$ & $36^{\circ} 33.72^{\prime}$ & $105^{\circ} 31.67^{\prime}$ & KF & $10.64,10.74$ & 3.515 & 83.5 & $22.7 \pm 1.0$ \\
\hline & 4342 & $-6 A$ & $36^{\circ} 33.72^{\prime}$ & $105^{\circ} 31.67^{\prime}$ & Bio. & $8.72,8.87$ & 2.409 & 69. & $18.9 \pm 0.9$ \\
\hline 34 & 3730 & $78 \mathrm{~L}-126 \mathrm{~A}$ & $36^{\circ} 39.16^{\prime}$ & $105^{\circ} 30.98^{\prime}$ & KF & $5.87,6.10$ & 2.290 & 71.5 & $26.4 \pm 1.2$ \\
\hline & 3769 & $78 \mathrm{~L}-126 \mathrm{~A}$ & $36^{\circ} 39.16^{\prime}$ & $105^{\circ} 30.98^{\prime}$ & Bio. & $5.90,5.95$ & 1.869 & 43.3 & $21.8 \pm 1.1$ \\
\hline 35 & 4340 & $80 \mathrm{~L}-20$ & $36^{\circ} 31.66^{\prime}$ & $105^{\circ} 30.66^{\prime}$ & KF & $7.66,7.76$ & 2.395 & 59.3 & $21.5 \pm 1.0$ \\
\hline & 4346 & $80 \mathrm{~L}-20$ & $36^{\circ} 31.66^{\prime}$ & $105^{\circ} 30.66^{\prime}$ & Bio. & $7.01,7.13$ & 1.923 & 56.3 & $18.8 \pm 0.9$ \\
\hline
\end{tabular}


TABLE 1. (continued)

\begin{tabular}{|c|c|c|c|c|c|c|c|c|c|}
\hline \multirow[b]{2}{*}{$\begin{array}{l}\text { Sam- } \\
\text { ple* }\end{array}$} & \multirow[b]{2}{*}{$\begin{array}{c}\text { DKA } \\
\text { Lab }\end{array}$} & \multirow[b]{2}{*}{ Field } & \multicolumn{2}{|c|}{ Location } & \multirow{2}{*}{$\begin{array}{c}\text { Rock } \\
\text { Type, } \\
\text { Mineral } \dagger\end{array}$} & \multirow[b]{2}{*}{$\underset{\%}{\mathbf{K}_{2} \mathbf{O}}$} & \multirow[b]{2}{*}{$\begin{array}{l}{ }^{40} \mathrm{Ar}^{*} \\
10^{-10} \\
\mathrm{~mol} / \mathrm{g}\end{array}$} & \multirow[b]{2}{*}{$\begin{array}{c}{ }^{40} \mathrm{Ar} * \\
\%\end{array}$} & \multirow[b]{2}{*}{$\underset{\mathrm{Ma}}{\text { Age }} \pm 2$ sd } \\
\hline & & & $\underset{\text { Latitude, }}{{ }^{\circ} \mathbf{N}}$ & $\begin{array}{l}\text { Longitude, } \\
{ }^{\circ} \mathbf{W}\end{array}$ & & & & & \\
\hline \multicolumn{10}{|c|}{ Younger Lava Flows } \\
\hline 41 & 4036 & $79 \mathrm{~L}-89$ & $36^{\circ} 52.16^{\prime}$ & $105^{\circ} 16.93^{\prime}$ & WR & $1.68,1.69$ & 0.367 & 70.4 & $15.1 \pm 0.8$ \\
\hline 42 & 4194 & $79 \mathrm{~L}-42$ & $36^{\circ} 56.98^{\prime}$ & $105^{\circ} 27.35^{\prime}$ & WR & $1.54,1.53$ & 0.350 & 50.9 & $15.8 \pm 0.9$ \\
\hline 43 & 4120 & 79L-93 & $36^{\circ} 53.67^{\prime}$ & $105^{\circ} 25.28^{\prime}$ & WR & $2.43,2.43$ & 0.547 & 75.0 & $15.6 \pm 0.8$ \\
\hline 44 & 4724 & Q83-SL31 & $37^{\circ} 01.20^{\prime}$ & $105^{\circ} 22.40^{\prime}$ & WR & $2.12,2.09$ & 0.330 & 65.6 & $10.9 \pm 0.4$ \\
\hline 45 & 4772 & $84 \mathrm{~L}-9$ & $36^{\circ} 52.57^{\prime}$ & $105^{\circ} 25.27^{\prime}$ & WR & $2.70,2.69$ & 0.608 & 67.8 & $15.6 \pm 0.7$ \\
\hline \multirow[t]{2}{*}{46} & 4193 & 79L-87 & $36^{\circ} 54.96^{\prime}$ & $105^{\circ} 24.95^{\prime}$ & Bio. & $8.94,8.88$ & 0.871 & 41.1 & $6.8 \pm 0.4$ \\
\hline & 4212 & 79L-87 & $36^{\circ} 54.96^{\prime}$ & $105^{\circ} 24.95^{\prime}$ & Plag. & $1.01,1.04$ & 0.170 & 25.2 & $11.5 \pm 0.8$ \\
\hline \multirow[t]{2}{*}{47} & 4773 & $84 \mathrm{~L}-8$ & $36^{\circ} 56.16^{\prime}$ & $105^{\circ} 23.98^{\prime}$ & Bio. & $8.74,8.78$ & 1.424 & 53.2 & $11.3 \pm 0.6$ \\
\hline & 4780 & $84 \mathrm{~L}-8$ & $36^{\circ} 56.16^{\prime}$ & $105^{\circ} 23.98^{\prime}$ & Hbl. & $1.37,1.38$ & 0.305 & 70.3 & $15.3 \pm 0.7$ \\
\hline 48 & 3607 & 77LRG107 & $37^{\circ} 00.00^{\prime}$ & $105^{\circ} 33.00^{\prime}$ & WR & $0.58,0.57$ & 0.036 & 12.2 & $4.3 \pm 0.8$ \\
\hline
\end{tabular}

Sample numbers same as in 1 able 4 ; locations shown on Figure 2 . Decay constants, ${ }^{40} \mathrm{~K}_{\lambda_{A}}=0.581$ $\times 10^{-10} \mathrm{yr}^{-1} ; \lambda_{\beta}=4.962 \times 10^{-10} \mathrm{yr}^{-1} ;{ }^{40} \mathrm{~K} / \mathrm{K}=1.167 \times 10^{-4}$ [Steiger and Jager, 1977].

*Sample notes: 1 , Hornblende rhyodacite; nearly glassy clast from basal flow breccia; mouth Gonzales Creek. 2, Nearly glassy clast in block and ash flow marginal to lava dome, Latir Peak Quartz Latite; above ski lift, ridge east of Cordova Creek. 3, Hornblende-plagioclase andesite; margins of hornblende phrenocrysts slightly oxidized; headwaters of Bitter Creek south of Cabresto Park. 4, Tuff of Tetilla Peak; nonwelded local ash flows around flanks of rhyolitic lava dome of Cordova Creek (7-8); lithic fragments abundant; divide between Cordova and Lemos creeks. 5, Rhyolite of Cordova Creek; lightgray sparsely porphyritic rhyolitic lava; Cordova Creek. 6, Hornblende-plagioclase andesite; hornblende phenocrysts oxidized; along road to Lemos Creek. 8, Vitrophyric black basal Amalia Tuff; densely welded; Cabresto Creek. 9, Glassy incipiently welded lowest exposed Amalia Tuff; First Creek section. 10, Densely welded devitrified upper Amalia Tuff; First Creek section. 11, Densely welded devitrified Amalia Tuff; slice in fault zone; muscovite mill site, Petaca. 13, Flow-laminated rhyolitic lava, directly overlying Amalia Tuff; Lemos Creek. 14, Densely welded devitrified Amalia Tuff; appears slightly silicified; Lemos Creek. 20, Quartz latite intrusion; light gray devitrified; Lemos Creek; same location as 21. 21, Quartz latite intrusion; black glassy margin; Lemos Creek; same location as 20. 22, Biotite rhyolite intrusion; black glassy margin; forms selvage around quartz latite (23); Commanche Point. 23, Quartz latite intrusion; light-gray devitrified; Comanche Point. 24, Quartz latite intrusion; light-gray devitrified; Comanche Point; recollection location 23. 25, Peralkaline arfvedsonite-acmite granite; near junction Virgin Canyon and Rito del Medio. 26, Biotite granite of Rito del Medio; light-gray miarolitic texture; base of cliff north of creek. 27, Biotite granite of Rito del Medio; collected near locality 26. 28, Biotitehornblende granite of Cabresto Lake pluton; along road to Cabresto Lake. 32, Biotite hornblende quartz monzonite in Hondo Canyon; roadcut in prominant rib north of road. 34, Granitic upper phase of Rio Hondo pluton; west fork of Columbine Creek. 35, Biotite granite of Lucero Peak pluton; prominant rib along Arroyo Seco, at stream level. 41, Xenocrystic basaltic andesite, interlayered with Santa Fe Group; Powderhouse Canyon. 42, Basanite; interlayered with sediments of Santa Fe Group; west of Amalia. 43, Silicic alkalic basalt; on flank of spatter cone; interlayered with sediments of Santa Fe Group; Costilla Creek, north of Cordova Creek. 44, Silicic alkalic basalt; flank of spatter cone above sediments of Santa Fe Group; Cuates Creek, Colorado. 45, Basaltic andesite mix lava, Ballejas Creek; shoulder east of 9783 hill. 46, Biotite-hornblende rhyolite lava done of Ute Creek; ridgecrest at TV relay station. 47, Biotite-hornblende rhyolite lava dome of Ute Creek; top of 9888 hill. 48 , Servilleta Basalt, San Pedro Mesa, Colorado (sample collected by M. A. Dungan).

$\uparrow$ Biot., biotite; Hbl., hornblende; KF, perthitic orthoclase; San., sanidine; Plag., plagioclase; Musc., muscovite; WR, whole rock. DKA, Denver K-Ar lab.

margin, only Precambrian rocks are exposed on the highest mountains at elevations of more than $4000 \mathrm{~m}$, and the preTertiary surface projects into the sky. Deep erosion of this differentially uplifted mountain block, combined with extensive rift-related faulting, provides exceptional exposures through the Latir field down into associated batholithic rocks interpreted as representing a cogenetic subvolcanic magma chamber [Lipman, 1983].

As documented in the present paper, the volcanic succession of the Latir field is slightly younger but otherwise generally similar to that of other Tertiary igneous accumulations in the southern Rocky Mountains: initial dominantly intermediatecomposition lavas and breccias erupted from clustered central volcanoes were followed by voluminous outpouring of silicic ash flow tuff associated with caldera collapse and emplacement of granitic rocks in the vent area. Scattered erosional remnants of the caldera-related ash flow sheet (the Amalia Tuff, a distinctive weakly peralkaline rhyolite) are preserved as far as $45 \mathrm{~km}$ from the source caldera. In contrast to other major ash flow regions in the southern Rocky Mountains, such as the San Juan and Thirtynine Mile volcanic fields [Steven, 1975; Epis and Chapin, 1968], only a single major ash flow sheet and only one large caldera formed in the Latir field. In addition, the Latir volcanics were erupted and associated intrusions were emplaced within a few million years, in contrast to more prolonged Tertiary igneous activity in adjacent areas.

Development of the Latir field coincided approximately in time with late Oligocene initiation of southwest directed extension in the region, as indicated by complex interrelations between volcanic structures of the Latir field and regional tectonic features [Lipman, 1983]. This early rifting along the Rio Grande zone has been interpreted as intraarc extension, related to waning of the mid-Tertiary volcanism above a subduction zone dipping gently beneath the cordillera margin of the American plate [Elston and Bornhorst, 1979; Lipman, 1981 ; Seager et al., 1984]. The extensional deformation led to formation of block-faulted topography across the entire width 
TABLE 2. Fission Track Analytical Data, Tertiary Rocks of the Latir Volcanic Field, New Mexico

\begin{tabular}{|c|c|c|c|c|c|c|c|c|c|c|}
\hline Sample* & Unit & $\begin{array}{l}\text { Field } \\
\text { and } \\
\text { Lab }\end{array}$ & Mineral & $\begin{array}{c}\text { U, } \\
\text { ppm }\end{array}$ & $\begin{array}{l}\text { Number } \\
\text { of } \\
\text { Grains }\end{array}$ & $\begin{array}{c}\text { Fossil } \\
\text { Tracks, } \\
\mathrm{cm}^{-2} \times 10^{6}\end{array}$ & $\begin{array}{c}\text { Induced } \\
\text { Tracks, } \\
\mathrm{cm}^{-2} \times 10^{6}\end{array}$ & $\begin{array}{l}\text { Neutrons, } \\
\times 10^{5} \mathrm{~cm}^{2}\end{array}$ & $r, s^{\prime}$ & $\begin{array}{c}\text { Age }+2 \text { sd } \\
\mathrm{Ma}\end{array}$ \\
\hline \multicolumn{11}{|c|}{ Volcanic Rocks: Precaldera Rocks } \\
\hline 2 & quartz latite breccia & $\begin{array}{l}83 \mathrm{~L}-12 \\
\text { DF-4761 }\end{array}$ & zircon & 310 & 6 & $\begin{array}{l}4.08 \\
(831)\end{array}$ & $\begin{array}{l}(9.84) \\
(1002)\end{array}$ & 1.02 & $0.93(r)$ & $25.2 \pm 2.6$ \\
\hline 2 & quartz latite breccia & $\begin{array}{l}83 \mathrm{~L}-12 \\
\text { DF-4760 }\end{array}$ & apatite & 4.1 & 50 & $\begin{array}{l}0.068 \\
(141)\end{array}$ & $\begin{array}{c}0.133 \\
(278)\end{array}$ & 1.02 & $0.14\left(s^{\prime}\right)$ & $30.9 \pm 8.7$ \\
\hline 4 & rhyolite tuff, Tetilla Peak & $\begin{array}{l}\text { 78L-179A } \\
\text { DF-2305 }\end{array}$ & zircon & 390 & 6 & $\begin{array}{l}5.18 \\
(1200)\end{array}$ & $\begin{array}{l}12.10 \\
(1401)\end{array}$ & 0.890 & $0.90(r)$ & $22.8 \pm 1.0$ \\
\hline 5 & rhyolite flow, Cordova Creek & $\begin{array}{l}83 \mathrm{~L}-8 \\
\mathrm{DF}-4759\end{array}$ & zircon & 450 & 6 & $\begin{array}{l}5.35 \\
(873)\end{array}$ & $\begin{array}{l}14.48 \\
(1173)\end{array}$ & 1.02 & $0.99(r)$ & $22.7 \pm 2.2$ \\
\hline \multicolumn{11}{|c|}{ Volcanic Rocks: Amalia Tuff and Related Rocks } \\
\hline 8 & outflow vitrophyre & $\begin{array}{l}82 \mathrm{~L}-37 \\
\mathrm{DF}-4470\end{array}$ & zircon & 620 & 6 & $\begin{array}{l}7.77 \\
(719)\end{array}$ & $\begin{array}{c}18.81 \\
(871)\end{array}$ & 0.963 & $0.99(r)$ & $23.7 \pm 1.1$ \\
\hline 11 & outflow, Petaca & $\begin{array}{l}82 \mathrm{~L}-38 \\
\text { DF-4471 }\end{array}$ & zircon & 460 & 6 & $\begin{array}{l}6.47 \\
(1139)\end{array}$ & $\begin{array}{l}13.89 \\
(1222)\end{array}$ & 0.963 & $0.99(r)$ & $26.8 \pm 1.2$ \\
\hline 13 & lava flow, Lemos Creek & $\begin{array}{l}\text { 78L-183 } \\
\text { DF-2310 }\end{array}$ & zircon & 270 & 6 & $\begin{array}{l}3.43 \\
(460)\end{array}$ & $\begin{array}{l}8.46 \\
(568)\end{array}$ & 0.888 & $0.97(r)$ & $21.5 \pm 1.0$ \\
\hline 14 & outflow, Lemos Creek & $\begin{array}{l}82 \mathrm{~L}-31 \\
\text { DF-4466 }\end{array}$ & zircon & 350 & 6 & $\begin{array}{l}4.39 \\
(854)\end{array}$ & $\begin{array}{l}10.72 \\
(1042)\end{array}$ & 0.963 & $0.84(r)$ & $23.6 \pm 1.4$ \\
\hline \multicolumn{11}{|c|}{ Intrusive Rocks: Northern Fault-Controlled Intrusions } \\
\hline 20 & quartz latite, Lemos Creek & $\begin{array}{l}\text { 78L-181 } \\
\text { DF-2307 }\end{array}$ & zircon & 300 & 6 & $\begin{array}{l}4.52 \\
(670)\end{array}$ & $\begin{array}{c}9.41 \\
(697)\end{array}$ & 0.889 & $0.98(r)$ & $25.1 \pm 1.1$ \\
\hline 20 & quartz latite, Lemos Creek & $\begin{array}{l}78 \mathrm{~L}-181 \\
\text { DF-2306 }\end{array}$ & apatite & 5.1 & 50 & $\begin{array}{l}0.079 \\
(164)\end{array}$ & $\begin{array}{l}0.161 \\
(335)\end{array}$ & 0.901 & $0.08(s)$ & $26.3 \pm 6.7$ \\
\hline 21 & quartz latite, Lemos Creek & $\begin{array}{l}83 L-16 \\
\text { DF-4763 }\end{array}$ & zircon & 290 & 6 & $\begin{array}{l}3.77 \\
(715)\end{array}$ & $\begin{array}{r}9.40 \\
(892)\end{array}$ & 1.02 & $0.97(r)$ & $24.4 \pm 2.7$ \\
\hline 24 & quartz latite, Commanche & $\begin{array}{l}82 L-34 \\
\text { DF-4467 }\end{array}$ & zircon & 240 & 6 & $\begin{array}{l}2.90 \\
(684)\end{array}$ & $\begin{array}{c}7.42 \\
(876)\end{array}$ & 0.963 & $0.90(r)$ & $22.5 \pm 1.2$ \\
\hline \multicolumn{11}{|c|}{ Intrusive Rocks: Intracaldera Plutons } \\
\hline 25 & Virgin Canyon pluton & $\begin{array}{l}80 L-27 \\
\text { DF-3514 }\end{array}$ & zircon & 230 & 8 & $\begin{array}{l}3.65 \\
(906)\end{array}$ & $\begin{array}{c}6.86 \\
(852)\end{array}$ & 0.870 & $0.97(r)$ & $27.6 \pm 1.4$ \\
\hline 26 & Rito del Medio pluton & $\begin{array}{l}80 \mathrm{~L}-52 \\
\mathrm{DF}-3515\end{array}$ & zircon & 475 & 6 & $\begin{array}{l}8.18 \\
(880)\end{array}$ & $\begin{array}{l}14.2 \\
(761)\end{array}$ & 0.870 & $0.99(r)$ & $30.0 \pm 1.4$ \\
\hline 28 & Cabresto pluton & $\begin{array}{l}78 \mathrm{~L}-172 \\
\text { DF-2303 }\end{array}$ & zircon & 300 & 7 & $\begin{array}{l}4.11 \\
(1142)\end{array}$ & $\begin{array}{c}9.24 \\
(1283)\end{array}$ & 0.891 & $0.94(r)$ & $23.7 \pm 1.0$ \\
\hline 28 & Cabresto pluton & $\begin{array}{l}78 L-172 \\
\text { DF-2301 }\end{array}$ & apatite & 50 & 6 & $\begin{array}{l}7.45 \\
(178)\end{array}$ & $\begin{array}{c}4.33 \\
(949)\end{array}$ & 4.33 & $0.99(r)$ & $24.3 \pm 2.3$ \\
\hline \multicolumn{11}{|c|}{ Intrusive Rocks: Caldera Ring Intrusions } \\
\hline 31 & Red River pluton & $\begin{array}{l}\text { RRGFT } \\
\text { DF-3561 }\end{array}$ & zircon & 410 & 6 & $\begin{array}{l}4.59 \\
(616)\end{array}$ & $\begin{array}{r}12.10 \\
(812)\end{array}$ & 0.941 & $0.95(r)$ & $21.3 \pm 1.1$ \\
\hline \multicolumn{11}{|c|}{ Intrusive Rocks: Southern Intrusions } \\
\hline 32 & Rio Hondo pluton & $\begin{array}{l}80 \mathrm{~L}-6 \mathrm{~A} \\
\text { DF-3512 }\end{array}$ & zircon & 378 & 6 & $\begin{array}{l}4.36 \\
(934)\end{array}$ & $\begin{array}{l}11.2 \\
(1206)\end{array}$ & 0.870 & $1.00(r)$ & $20.1 \pm 0.9$ \\
\hline 32 & Rio Hondo pluton & $\begin{array}{l}\text { 80L-6A } \\
\text { DF-3517 }\end{array}$ & apatite & 6.0 & 100 & $\begin{array}{l}0.0397 \\
(125)\end{array}$ & $\begin{array}{c}0.191 \\
(602)\end{array}$ & 0.926 & $0.046\left(s^{\prime}\right)$ & $11.5 \pm 2.2$ \\
\hline 33 & Rio Hondo pluton & $\begin{array}{l}\text { NM/H-1 } \\
\text { DF-535 }\end{array}$ & zircon & 450 & 6 & $\begin{array}{l}5.06 \\
(773)\end{array}$ & $\begin{array}{l}18.7 \\
(1430)\end{array}$ & 1.27 & $0.97(r)$ & $21.0 \pm 1.9$ \\
\hline 33 & Rio Hondo pluton & $\begin{array}{l}\text { NM/H-1 } \\
\text { DF-536 }\end{array}$ & apatite & 10 & 50 & $\begin{array}{l}0.979 \\
(204)\end{array}$ & $\begin{array}{c}4.41 \\
(918)\end{array}$ & 1.29 & $0.056\left(s^{\prime}\right)$ & $17.6 \pm 1.8$ \\
\hline 34 & Rio Hondo pluton & $\begin{array}{l}78 \mathrm{~L}-126 \mathrm{~A} \\
\mathrm{DF}-2300\end{array}$ & zircon & 390 & 6 & $\begin{array}{l}4.84 \\
(1210)\end{array}$ & $\begin{array}{l}12.10 \\
(1512)\end{array}$ & 0.893 & $0.87(r)$ & $21.4 \pm 1.0$ \\
\hline 34 & Rio Hondo pluton & $\begin{array}{l}78 \mathrm{~L}-126 \mathrm{~A} \\
\text { DF-2298 }\end{array}$ & apatite & 10 & 6 & $\begin{array}{c}0.104 \\
(58)\end{array}$ & $\begin{array}{c}1.54 \\
(120)\end{array}$ & 3.8 & $0.64(r)$ & $17.6 \pm 3.8$ \\
\hline 35 & Lucero Peak pluton & $\begin{array}{l}80 \mathrm{~L}-20 \\
\text { DF-3513 }\end{array}$ & zircon & 871 & 6 & $\begin{array}{l}10.5 \\
(1027)\end{array}$ & $\begin{array}{l}36.0 \\
(1271)\end{array}$ & 0.870 & $1.00(r)$ & $21.0 \pm 1.0$ \\
\hline 35 & Lucero Peak pluton & $\begin{array}{l}80 \mathrm{~L}-20 \\
\text { DF-3516 }\end{array}$ & apatite & 8.4 & 50 & $\begin{array}{l}0.068 \\
(299)\end{array}$ & $\begin{array}{r}0.265 \\
(1160)\end{array}$ & 0.928 & $0.041\left(s^{\prime}\right)$ & $14.3 \pm 2.0$ \\
\hline 36 & Lucero Peak pluton & $\begin{array}{l}\text { LPGFT } \\
\text { DF-3560 }\end{array}$ & zircon & 700 & 6 & $\begin{array}{c}7.87 \\
(1166)\end{array}$ & $\begin{array}{l}21.07 \\
(1561)\end{array}$ & 0.944 & $0.72(r)$ & $21.1 \pm 1.3$ \\
\hline
\end{tabular}

Decay constant: $7.03 \times 10^{-17} \mathrm{yr}^{-1}$; parentheses indicate number of tracks counted; sd, standard deviation; $r$, correlation coefficient; $s^{\prime}$, standard error of mean induced count.

*Sample notes (locations and descriptions in Table 1, except as follows): 31, Fine-grained granite; mouth of Mallete Creek (collected and analyzed by P. Billings). 33, Reanalysis of sample originally reported by Naeser [1967]. 36, Biotite granite of Lucero Peak pluton; Arroyo Seco (collected and analyzed by $P$. Billings). 


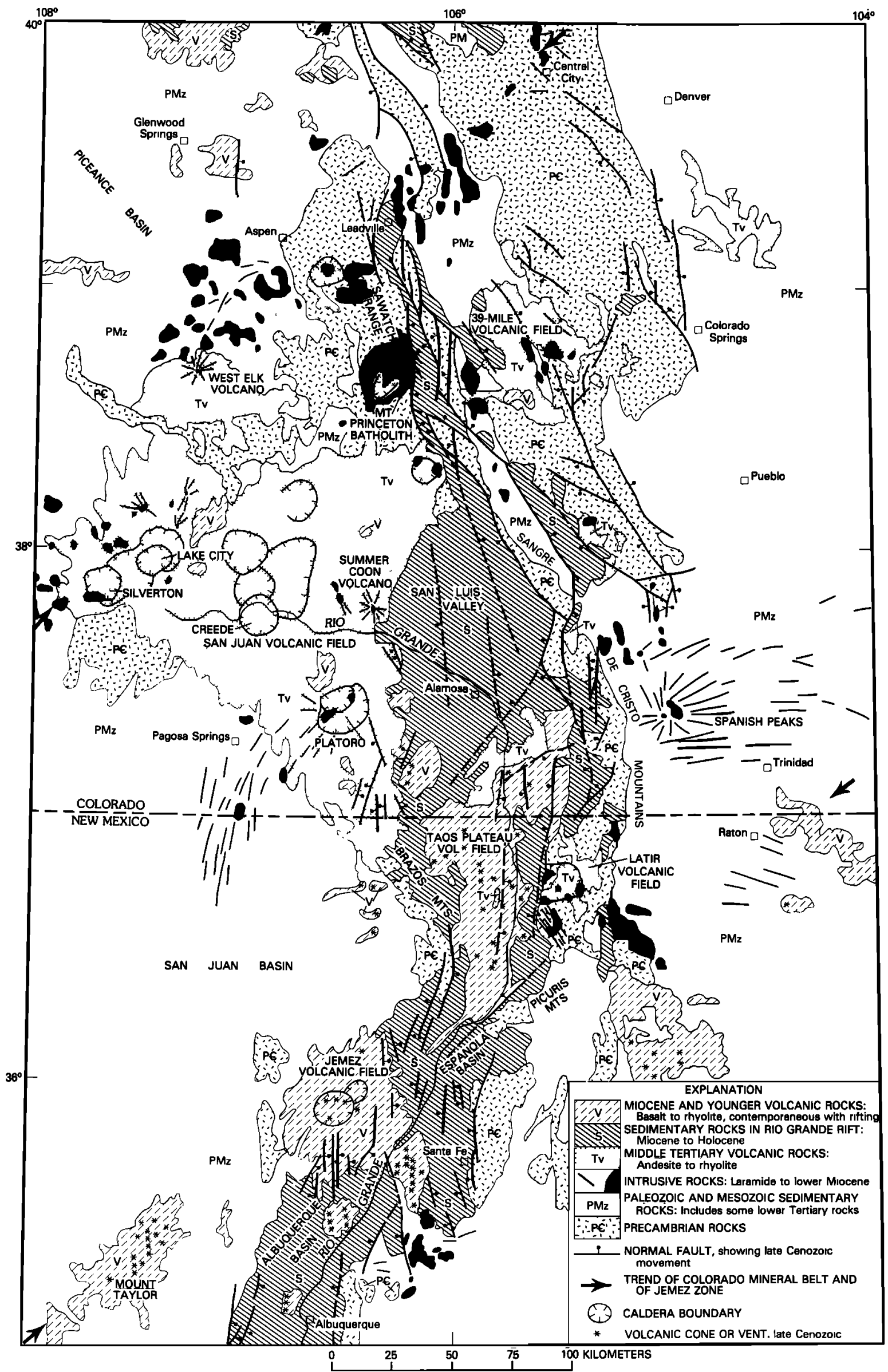

Fig. 1. Regional geologic map of the southem Rocky Mountains, showing location of the Latir volcanic field and associated Questa caldera in relation to extent of major Laramide and Tertiary intrusions, Tertiary volcanic rocks, and late Cenozoic extensional faults [from Lipman, 1981]. 


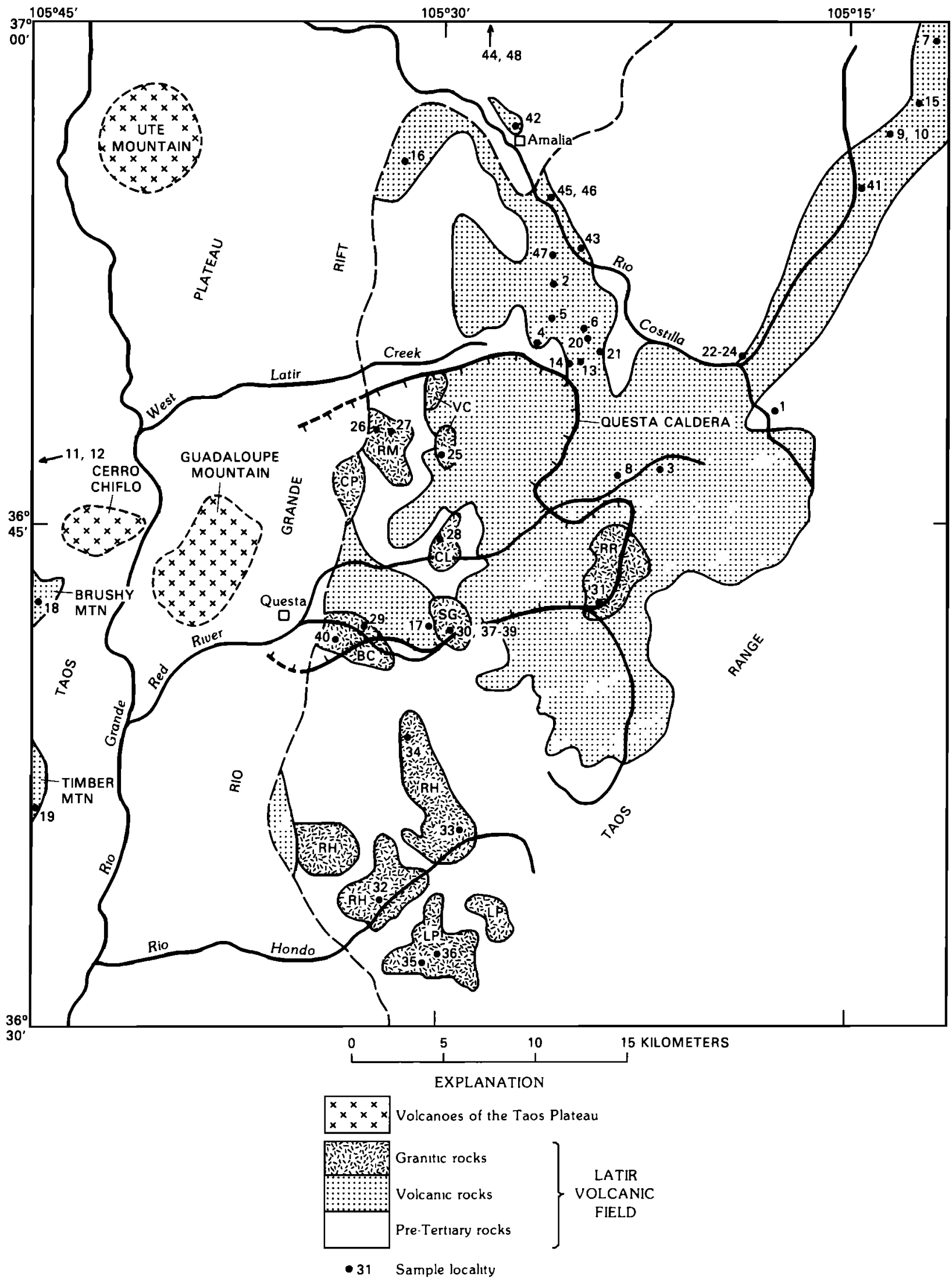

Fig. 2. Diagramatic geologic map of the Latir volcanic field, showing localities of analyzed samples (Table 3). Dashed line indicates margins of mountainous areas; hachured line, topographic wall of the Questa caldera (dashed, where concealed in Rio Grande rift). Abbreviations for granitic plutons: BC, Bear Canyon; CL, Cabresto Lake; CP, Canada Pinabete; SG, Sulfur Gulch; LP, Lucero Peak; RH, Rio Hondo; RM, Rito del Medio; RR, Red River; VC, Virgin Canyon. 
of the southern Rocky Mountains in northern New Mexico: events that mark inception of the Rio Grande rift [Lipman, 1983]. The broad region of southwest directed extension was overprinted, beginning sometime between about 15 and $5 \mathrm{Ma}$, by more nearly westward extension focused along a narrower zone that blocked out the present-day Rio Grande rift. Within the rift zone near the Questa area, exposed rocks are mostly Pliocene volcanics of the Taos Plateau field [Lipman and Mehnert, 1979; Dungan et al., 1984], including several topographically prominent central volcanoes (Figure 2).

\section{Tertiary Volcanic Sequence}

Oligocene-Miocene rocks of the Latir volcanic field directly overlie Precambrian metamorphic and plutonic rocks over large areas; locally, they rest on discontinuously preserved lower Tertiary sedimentary deposits that record unroofing of the Precambrian as a result of Laramide deformation and subsequent erosion [Lucas, 1984]. Prior to formation of the Questa caldera, the Latir field consisted of a group of dominantly intermediate-composition stratovolcanoes and lava domes; these volcanoes were surrounded by aprons of volcaniclastic debris, which were clustered within the area of subsequent caldera collapse [Lipman, 1983]. Preserved erosional remnants of these volcanoes and related sediments are overlain by the regional ash flow sheet and local lava flows of silicic alkalic rhyolite erupted during collapse of the Questa caldera. After caldera formation, Miocene sedimentary rocks of the Santa Fe Group and local interbedded basaltic flows accumulated widely within the region of the Latir field in growing fault-block basins of the early Rio Grande rift (Table 3).

The Latir volcanic rocks are widely propylitized, and local oxidation of hydrothermal pyrite has led to intense supergene leaching. Propylitic alteration is, in effect, low-grade thermal metamorphism, with the stable propylitic assemblage in the andesitic rocks being albite-epidote-chlorite-calcite. In addition, some associated volcaniclastic sedimentary rocks close to granitic contacts have the dense flinty character of contact metamorphic hornfels. The general distribution of the lowgrade thermally metamorphosed and hydrothermally altered rocks correlates well with exposed intrusive rocks and geophysical interpretations of their subsurface extent. Samples for radiometric dating were collected mainly around the north margin of the preserved volcanic sequence, where effects of metamorphism and alteration have been minimal. Even so, material suitable for dating is not widely preserved, especially for the precaldera volcanic units. Some samples have yielded discordant ages on mineral pairs, and some results are inconsistent with stratigraphic relations, as noted below.

\section{Precaldera Volcanic Rocks}

Products of early volcanoes in the Latir field vary in composition from basaltic to rhyolitic lavas and tuffs. Ages for seven compositionally diverse precaldera volcanic units have been determined (Table 4). Together with results from overly-

TABLE 3. Generalized Tertiary Igneous and Stratigraphic Sequence of the Latir Volcanic Field

\begin{tabular}{|c|c|c|c|}
\hline Unit & $\begin{array}{l}\text { Age, } \\
\text { Ma }\end{array}$ & $\begin{array}{c}\mathrm{SiO}_{2} \\
\text { Content, } \\
\text { wt } \%\end{array}$ & $\begin{array}{l}\text { Composition and } \\
\text { Distinctive Features }\end{array}$ \\
\hline \multicolumn{4}{|l|}{ Rift-related sedimentary and volcanic rocks } \\
\hline \multicolumn{4}{|l|}{ Santa Fe Group } \\
\hline Sediments from Precambrian sources & $5-15$ & & silt to fanglomerate \\
\hline Sediments from volcanic sources & $16-22$ & & $\begin{array}{l}\text { mostly conglomerate (equivalent to } \\
\text { Los Pinos Formation) }\end{array}$ \\
\hline Basaltic lava flows & $11-16$ & $44-51$ & basanite to silicic alkalic basalt \\
\hline \multicolumn{4}{|l|}{ Intrusive rocks, Questa magmatic system } \\
\hline \multicolumn{4}{|l|}{ Late mineralized plutons } \\
\hline Lucero pluton & $21-22$ & 76 & medium-grained granite \\
\hline Intrusions along south caldera margin & $22-23$ & $76-77$ & aplite and granite porphyry \\
\hline \multicolumn{4}{|l|}{ Intracaldera plutons } \\
\hline Rito del Medio pluton & $25-26$ & 76 & medium-grained granite; myriolitic \\
\hline Canada Pinabete pluton & $25-26$ & 76 & medium- to fine-grained granite \\
\hline Virgin Canyon intrusion & 26 & 76 & $\begin{array}{l}\text { acmite-arfvedsonite granite } \\
\text { and rhyolite porphyry }\end{array}$ \\
\hline Cabresto Lake pluton & $25-26$ & 72 & biotite-hornblende granite \\
\hline \multicolumn{4}{|l|}{ Southern batholithic rocks } \\
\hline Rio Hondo plutons & $25-26$ & $64-76$ & $\begin{array}{l}\text { porphyritic quartz monzite, } \\
\text { locally grading upward into granite }\end{array}$ \\
\hline Northern fault-controlled intrusions & $26-27$ & $65-72$ & porphyritic quartz latite and rhyolite \\
\hline Amalia Tuff and cogenetic lava flows & 26.5 & $77-80$ & $\begin{array}{l}\text { rhyolitic ash flow tuff and lavas; } \\
\text { quartz and sodic san. phenocrysts }\end{array}$ \\
\hline \multicolumn{4}{|l|}{ Precaldera volcanic rocks } \\
\hline Comendite of Ortiz Peak & $26.5-27$ & 72 & $\begin{array}{l}\text { thick flows and domes; large blocky } \\
\text { sanidine phenocrysts }\end{array}$ \\
\hline Latir Peak quartz latite & $27-28$ & $64-66$ & $\begin{array}{l}\text { thick flows and domes; plag., bio., } \\
\text { and hbl. phenocrysts }\end{array}$ \\
\hline Andesitic and rhyodacitic flows & $27-28$ & $57-64$ & $\begin{array}{l}\text { variable in composition and texture; } \\
\text { from many clustered volcanoes }\end{array}$ \\
\hline Tuff of Tetilla Peak and related lavas & $27-28$ & $70-72$ & $\begin{array}{l}\text { weakly welded lithic tuff, associated with } \\
\text { rhyolitic flows and domes }\end{array}$ \\
\hline Early Tertiary sedimentary rocks & Eocene(?) & & $\begin{array}{l}\text { discontinuous post-Laramide weakly } \\
\text { indurated sedimentary rocks }\end{array}$ \\
\hline
\end{tabular}

Modified from Lipman [1983]. 


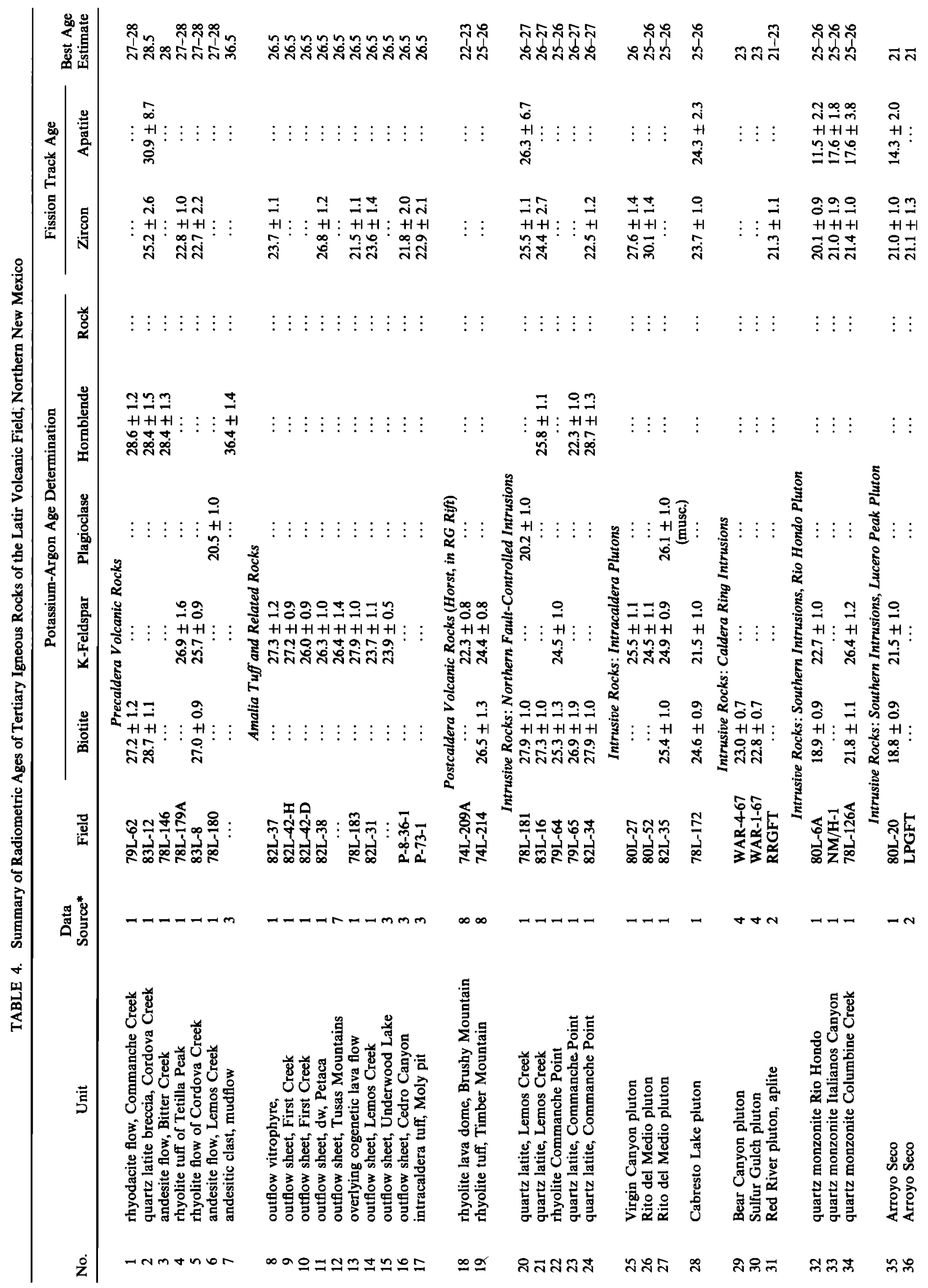




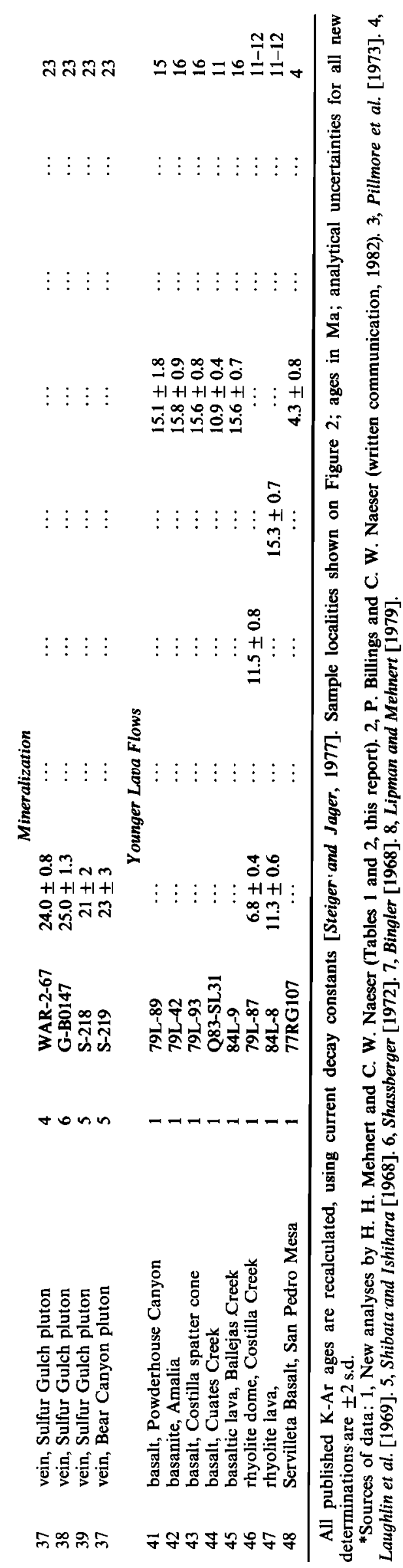

ing caldera-related units, these ages suggest that the bulk of precaldera volcanism in the Latir field occurred in a geologically brief period between about 28.5 and $26.5 \mathrm{Ma}$.

The freshest materials analyzed were almost glassy clasts from two breccias associated with rhyodacite and quartz latite lava flows low in the volcanic sequence. Both samples yielded concordant $\mathrm{K}$-Ar ages on biotite-hornblende mineral pairs, in the range $27-28.5$ Ma (Table 4, numbers 1-2). A slightly oxidized andesite flow, at an intermediate stratigraphic level east of the caldera, yielded a hornblende $\mathrm{K}-\mathrm{Ar}$ age of $28.4 \mathrm{Ma}$ (Table 4, number 3), in reasonable agreement with the other ages just summarized.

In contrast, rhyolitic lava and associated tuff at or near the base of the volcanic sequence, that lie stratigraphically below the intermediate-composition rocks just discussed, yielded slightly younger $\mathrm{K}-\mathrm{Ar}$ ages on biotite and sanidine: $25.7-27.0$ Ma (Table 4, numbers 4-5). Although phenocrysts in these rhyolites appear unaltered in thin section, their ages are thought to reflect slight thermal resetting, due to younger caldera-related intrusions to the south. Fission track zircon ages from the rhyolites are also anomalously young, at 22.7$22.8 \mathrm{Ma}$.

Similarly, an andesite in Lemos Creek near the northeast caldera margin, that is stratigraphically below the $28 \mathrm{Ma}$ quartz latite, yielded a reset $\mathrm{K}-\mathrm{Ar}$ date of only $20.5 \mathrm{Ma}$ on plagioclase (Table 4, number 6). An anomalously young $\mathrm{K}-\mathrm{Ar}$ date was also obtained from nearby Amalia Tuff in Lemos Creek (Table 4, number 14), in accord with interpretation that this area has been thermally disturbed.

A published K-Ar age of $36.4 \mathrm{Ma}$ [Pillmore et al., 1973], determined on hornblende from an andesitic clast within a stratigraphically low mudflow deposit $35 \mathrm{~km}$ northeast of the Questa caldera, is $8 \mathrm{~m}$.y. older than any other data thus far determined for the Latir field (Table 4, number 7). Accordingly, this material is tentatively interpreted as derived from unrelated volcanic sources to the north or northwest, marginal to the San Juan volcanic field in Colorado (Figure 1).

\section{Amalia Tuff and Related Rocks}

Welded tuff of high-silica rhyolite, the Amalia Tuff, accumulated within the Questa caldera to a thickness of $2 \mathrm{~km}$ or more during collapse and spread widely as a thin regional ash flow sheet outside the caldera. This is the only major ash flow sheet of the Latir volcanic field. It is weakly compositionally zoned, from alkalic fayalite rhyolite at its base, upward into peralkaline rhyolite in which sodic amphibole is locally preserved. Due to its peralkaline composition, it is petrographically and chemically unique in the southern Rocky Mountains and is readily distinguished from any other ash flow unit in the region. Associated with eruption of the Amalia Tuff is petrologically similar flow-laminated rhyolitic lava, that is preserved locally north and south of the caldera.

Five widely separated samples of the outflow Amalia Tuff have yielded $\mathrm{K}$-Ar sanidine ages of $26.0-27.3$ Ma (Table 4, numbers 8-12), with a mean of $26.6 \mathrm{Ma}$ that is considered the best present approximation of the age of the tuff. Two samples are from the Tusas (Brazos) Mountains, $35-45 \mathrm{~km}$ across the Rio Grande rift west of the caldera; two samples are from upper and lower parts of a thick valley fill section of the tuff about $25 \mathrm{~km}$ north of the caldera; and one sample is from a rare basal vitrophyre of the tuff a few kilometers east of the caldera margin. A zircon F-T age of $26.8 \pm 1.2 \mathrm{Ma}$ was also determined on one of the Amalia Tuff samples from the Tusas Mountains. A rhyolitic lava flow that overlies the tuff and is chemically similar yielded a sanidine K-Ar age of $27.9 \pm 1.1$ 
Ma (Table 4, number 13), slightly older but within analytical uncertainty of the mean age of the tuff.

K-Ar and F-T dates on four additional samples of Amalia Tuff, including three published previously [Pillmore et al., 1973], are in the range $23.9-21.8 \mathrm{Ma}$, apparently reflecting resetting due to thermal effects of the shallow batholith beneath the Latir volcanic field. Seemingly unaltered tuff from a few kilometers northeast of the caldera, yielded a $\mathrm{K}$-Ar age on sanidine of only $23.7 \mathrm{Ma}$ (Table 4, number 14), even though overlain at this site by the dated rhyolitic lava flow (27.9 Ma) just described. A previously determined $\mathrm{K}-\mathrm{Ar}$ sanidine age of 23.9 (Table 4, number 15), from the tuff $25 \mathrm{~km}$ north of the caldera, is perplexing because two newly determined samples from the same general area yielded consistent older ages (Table 4, numbers 9-10).

Two previously determined F-T zircon ages on the tuff, that are anomalously young, are more readily interpreted. One, dated at 22.9 Ma (Table 4, number 17), is from the Questa Mine, within the southern part of the caldera and adjacent to a mineralized granite dated by $\mathrm{K}-\mathrm{Ar}$ at $22.8 \mathrm{Ma}$ (Table 4 , number 30). The other zircon F-T age, $21.9 \mathrm{Ma}$ (Table 4, number 16), is from near the type area of the tuff at the small town of Amalia $10 \mathrm{~km}$ north of the caldera; this locality is within an area of potassium metasomatism that has drastically modified the chemistry of the tuff [Lipman, 1983, p. 139]. The potassium metasomatism is interpreted as due to effects from a then active hydrothermal system, that probably also reset the F-T age of the tuff in this area. Several tuff and lava samples close to the caldera, that have $\mathrm{K}$-Ar ages at about 26-27 Ma, also yielded anomalously young F-T ages (Table 4, numbers 8 and 13). These anomalous dates indicate that the regional thermal gradient was maintained for several million years (or reestablished) close to that needed to anneal fission tracks in zircon. The younger dates are accordingly interpreted as the times of cooling below zircon annealing temperatures, about $230^{\circ} \mathrm{C}$ [Hurford, 1984].

\section{Postcaldera Volcanic Rocks}

No postcaldera volcanic rocks related to the Questa magmatic system have been identified within the Latir Mountains, other than peralkaline rhyolite lavas that are coeval with the Amalia Tuff. Small exposures of compositionally diverse postcaldera rocks are preserved at Brushy and Timber Mountains, on the largely buried horst within the Rio Grande rift west of Questa (Figures 1 and 2) [Lipman and Mehnert, 1979], as indicated by stratigraphic, geochronologic, and petrologic features.

A rhyolitic lava dome at Brushy Mountain, dated at 22.3 Ma (Table 4, number 18), is part of a local lava sequence that overlies the Amalia Tuff on the horst block [Thompson and Dungan, 1984]. The rhyolite at Brushy Mountain is chemically similar to the 21-23 Ma mineralized granites in the Questa area and may represent a volcanic counterpart to intrusive activity near the buried western caldera margin.

A stratigraphically lower volcanic sequence on the horst at Timber Mountain $5 \mathrm{~km}$ south of Brushy Mountain, consists largely of intermediate-composition lava flows distinguished by high alkali and enriched minor-element contents [Thompson and Dungan, 1984], similar to lavas erupted in the Latir Mountains just before formation of the Questa caldera. An ash flow tuff of low-silica rhyolite, at the base of the exposed sequence at Timber Mountain, yielded biotite and sanidine $\mathrm{K}$-Ar ages of 26.5 and $24.4 \mathrm{Ma}$, respectively (Table 4 , number 19). These ages, in conjunction with the absence of Amalia
Tuff at exposed levels in this section, provide evidence that the Timber Mountain sequence represents postcaldera activity, generally continuing the compositional trends of the last precaldera lavas [Thompson and Dungan, 1984].

Volcanic clasts are abundant in rift fill sedimentary sequences west of the Latir Mountains, including the Los Pinos Formation and parts of the Santa Fe Group [Manley, 1981]. $\mathrm{K}$-Ar determinations on biotite phenocrysts from four andesitic-dacitic clasts from the Los Pinos Formation and from the Chama-El Rito Member of the Tesuque Formation (Santa Fe Group) in the Espanola Basin yielded ages in the range 21.7-22.6 Ma [Ekas et al., 1984]. In conjunction with paleocurrent studies indicating a primary volcanic source to the northeast of the Espanola Basin, these ages suggest derivation from postcaldera rocks of the Latir field, similar to (and slightly younger than) those exposed on the intrarift horst west of Questa. Thus, although the record is fragmentary, postcollapse volcanism associated with the Latir field may have extended over about $4 \mathrm{~m}$.y. (26-22 Ma), as long or longer than the period of precaldera activity.

\section{INTRUSIVE ROCKS}

Intrusive rocks associated with the Questa caldera and the Latir volcanic field include discontinuously exposed cogenetic batholithic granitic rocks and a compositionally and texturally diverse assemblage of porphyritic dikes, sills, and irregular laccoliths [Lipman, 1983]. These porphyro-aphanitic intrusions occur along regional faults north and south of the Questa caldera, as well as in a major dike swarm, generally trending northwest, within and over the roof of the batholithic granitic rocks south of the caldera. Granitic rocks are discontinuously exposed along an elongate resurgent uplift within the caldera, in shallow cupolas of a large ring intrusion along the south caldera margin, and beneath large areas south of the caldera (Figure 2).

\section{Northern Fault-Controlled Intrusions}

Porphyritic quartz latite and rhyolite form irregular dikes and sills, emplaced along regional Tertiary normal faults related to early extension along the Rio Grande rift north of the Questa caldera. Attempts were made to date these rocks in some detail, because their ages help constrain initiation of rift faulting.

Two bodies of quartz latite and an associated rhyolite have yielded $\mathrm{K}$-Ar ages of 25-28 Ma (Table 4, numbers 20-24). Initial results were discordant for both bodies of quartz latite, reflecting mineral separation or analytical problems. Replicate analyses of additional samples yielded more concordant ages, although geologic relations still are locally at odds with the radiogenic data. The rhyolite at Commanche Point yielded slightly younger $\mathrm{K}$-Ar ages, 25.3 and $24.5 \mathrm{Ma}$ on biotite and sanidine, respectively; however, the rhyolite is structurally closely related to the quartz latite in the same area, forming the margins of an irregular laccolith cored by quartz latite. Accordingly, both rock types are believed similar in age. A seemingly conformable sequence of volcanic units of the Latir field, including the Amalia Tuff, is cut by faults that control emplacement of the quartz latite, indicating that much of the faulting is younger than about $26.5 \mathrm{Ma}$, despite the slightly older $\mathrm{K}$-Ar ages for some minerals from the quartz latite. Some thermal disturbance of the age relations is also indicated by F-T zircon dates for the quartz latites that are consistently younger than the K-Ar results. 


\section{Intracaldera Plutons}

Several texturally and compositionally distinct granitic bodies intrude Tertiary volcanics and underlying Precambrian rocks within central and northern parts of the caldera floor (Figure 2). These granites, which form discrete plutons at present exposure levels, are collectively interpreted as closely related bodies of only slightly differing ages related to postcollapse resurgence of the caldera. They contain only minor associated altered or mineralized rock at presently exposed levels.

The topographically and structurally highest of these bodies, exposed in Virgin Canyon (a major tributary of Rito del Medio), varies from equigranular biotite granite $(74-76 \%$ $\mathrm{SiO}_{2}$ ) to a distinctive marginal peralkaline phase of arfvedsonite-acmite granite and rhyolite porphyry. This border phase of the Virgin Canyon pluton is chemically similar to late-erupted Amalia Tuff and is interpreted as representing a quenched residue of the magma that was largely erupted to form the ash flow tuff. This body has yielded approximately concordant K-Ar sanidine and F-T zircon ages at about $26 \mathrm{Ma}$ (Table 4, number 25), confirming its close petrologic association with the caldera-forming eruption of the 26.5 Ma Amalia Tuff.

The largest intracaldera intrusive masses, exposed low along the western mountain front at Rito del Medio and Canada Pinabete (Figure 2), consist of fine- to medium-grained equigranular silicic granite containing sparse biotite. These rocks are high-silica granites, similar to the interior of the Virgin Canyon pluton; the granitic intrusion along Canada Pinabete also locally contains marginal peralkaline phases. The Rito de Medio body has yielded nearly accordant $\mathrm{K}$-Ar dates on perthitic orthoclase and on micas from two samples that cluster at 25-26 Ma (Table 4, numbers 26-27), as well as an anomalously old zircon F-T age (at $30 \pm 1.4 \mathrm{Ma}$ ) that is contradicted by geologic relations. Despite the general concordance in $\mathrm{K}-\mathrm{Ar}$ ages and petrologic similarity to the biotite-bearing metaluminous interior of the Virgin Canyon pluton, paleomagnetic data indicate that the Rito del Medio body is less tilted by regional faults related to the Rio Grande rift and therefore slightly younger than the Virgin Canyon pluton [Hagstrum et al., 1982; Hagstrum and Lipman, 1984].

Southeast of Rito del Medio, the roof zone level of a biotitehornblende granite along Cabresto Lake is also exposed along the crest of the resurgent caldera core. Typical rocks of the Cabresto Lake pluton are low-silica granite $\left(72-73 \% \mathrm{SiO}_{2}\right)$, transitional between the more fractionated granites farther northwest within the caldera and less evolved quartz monzonite of the Rio Hondo pluton to the south outside the caldera. The Cabresto Lake pluton has yielded discordant K-Ar and F-T dates, between 24.6 and 21.5 Ma (Table 4, number 28), that are interpreted as probably recording the time of initial emplacement and cooling at about 25-26 Ma, followed by reheating and partial resetting in conjunction with emplacement of nearby intrusions along the southern caldera margin at about $22-23 \mathrm{Ma}$, as discussed below.

\section{Caldera Ring Intrusions}

Three pyritized and hydrothermally altered plutons containing molybdenum mineral deposits are aligned east-west along the southern margin of the caldera, following the Red River (Figure 2). These plutons postdate caldera collapse and intrude both Precambrian rocks of the caldera wall and Tertiary volcanic units of the caldera floor and fill, including the Amalia Tuff. Their roof zones are highest within upthrown blocks bounded by north or northwest trending fault systems that cross the caldera margin. These plutons are thought to be fault-localized cupolas along an intrusive mass that is continuous at shallow depth, representing a partial ring intrusion along the south caldera margin. Published K-Ar biotite ages on the western and central plutons (Bear Canyon, Sulfur Gulch) are similar at about 23 Ma (Table 4, numbers 29-30 [Laughlin et al., 1969]). A new F-T age on zircon from aplitic granite of the Red River intrusive complex to the east is slightly younger at $21 \mathrm{Ma}$ (Table 4, number 31), but not significantly so.

The emplacement age for all three intrusions along the southern caldera margin intrusions is thus considered most probably to be about $22-23 \mathrm{Ma}$, based on the published $\mathrm{K}-\mathrm{Ar}$ ages. These intrusions are accordingly plausible condidates for the thermal perturbation of the caldera area that has caused widespread radiogenic discordances in older Tertiary rocks. Alternatively, still younger intrusive phases could be present at depth, and the radiogenic ages of the southern calderamargin intrusions could be partially reset and represent only minimum ages.

\section{Southern Intrusions}

The largest exposed Tertiary intrusive bodies in the Questa area are batholithic masses of quartz monzonite as much as 9 $\mathrm{km}$ across in the Rio Hondo and adjacent drainages (Figure 2). Contacts with Precambrian country rock are variable in dip but are gentle over large areas that represent roof zones of the intrusion. At present exposure levels, much of the Precambrian country rock occurs along ridge crests; gently dipping contacts with the underlying quartz monzonite clearly connect at similar altitudes. Along this roof zone, the quartz monzonite grades irregularly into silicic granite. The roof zone of the Rio Hondo batholith is also cut by hundreds of northwest trending rhyolite dikes and lesser numbers of more mafic dikes, interpreted as representing intrusion of liquid interior portions of the batholith into the consolidated margins.

$\mathrm{K}-\mathrm{Ar}$ and F-T ages from three geologically separate samples of the Rio Hondo batholith are discordant, varying from 26 to $19 \mathrm{Ma}$ (Table 4, numbers 32-34). Rb/Sr mineral isochrons for two samples, from both northern (Columbine Creek) and southern (Rio Hondo) parts of the batholith, yield identical ages of $25.7 \pm 0.2 \mathrm{Ma}$ (M. C. Johnson, written communication, 1983). These results indicate primary cooling of the batholithic quartz monzonite at about 26-25 Ma, concurrently with emplacement of the resurgent intrusions within the caldera to the north. This intrusive event was followed by variable thermal resetting of $\mathrm{K}-\mathrm{Ar}$ and $\mathrm{F}-\mathrm{T}$ systems associated with emplacement of a second group of younger intrusions at 21-23 Ma.

A second major intrusion in the southern area, well exposed on Lucero Peak south of Rio Hondo, is relatively coarse silicic equigranular granite that is everywhere separated from the Rio Hondo pluton by a septum of Precambrian rocks (Figure 2). Contacts of the Lucero pluton dip gently to steeply outward. K-Ar and F-T ages for the Lucero pluton are fairly concordant at about $21 \mathrm{Ma}$ (Table 4, numbers 35-36), suggesting emplacement and cooling roughly concurrently with the mineralized intrusions along the southern caldera margin to the north; an anomalously young $\mathrm{K}-\mathrm{Ar}$ age on biotite of 18.8 $\mathrm{Ma}$ hints at a still younger thermal event. In contrast to the Rio Hondo pluton, the main mass of the Lucero Peak pluton lacks crosscutting dikes, suggesting a younger emplacement age in agreement with the geochronologic data. However, an eastern outlier of the Lucero body is cut by dikes, locally altered, and contains pyrite and molybdenite [Ludington, 1981 ; Jones and Norris, 1984]. These relations suggest that at 


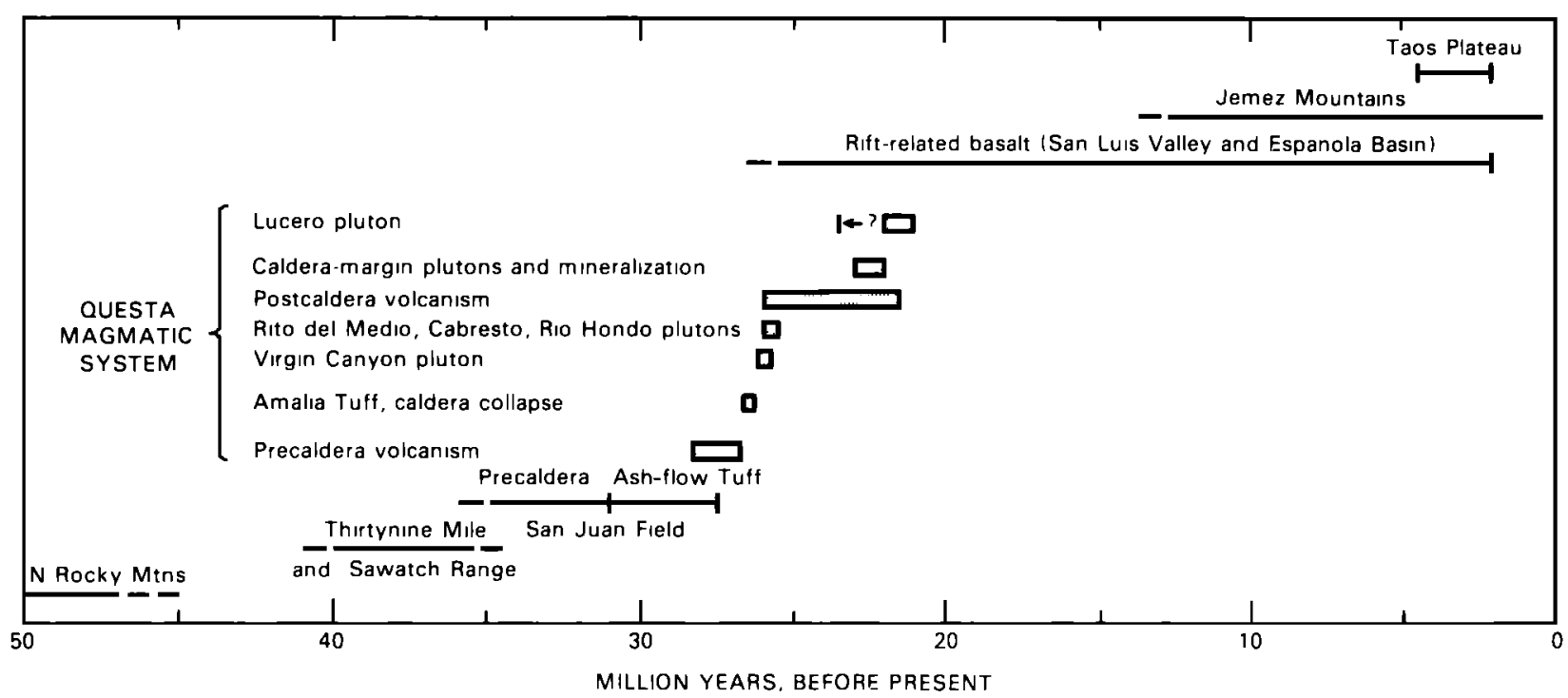

Fig. 3. Interpreted time sequence for major igneous events, Latir volcanic field and Questa caldera, in comparison with time spans for major preceding igneous regions in the Rocky Mountains and subsequent volcanism along the Rio Grande rift in northern New Mexico and southern Colorado.

least some dikes cutting the Rio Hondo pluton may be petrologically related to the Lucero pluton and similar in age at about 21-23 Ma. Emplacement of the Lucero pluton and such associated dikes probably also caused some resetting of $\mathrm{K}-\mathrm{Ar}$ and F-T ages in adjacent southern parts of the Rio Hondo pluton.

\section{Mineralization}

Tertiary mineralization in the region consists primarily of large porphyry molybdenum deposits associated with the intrusions along the southern caldera margin, and to a lesser degree, the exploration targets associated with the Lucero Peak pluton [Leonardson et al., 1983; Ludington, 1981]. Scattered small precious- and base metal veins south and southeast of the caldera have been sparsely productive and little studied geologically [Clark and Read, 1972]. Published K-Ar dates on coarse hydrothermal vein biotite, associated with the molydenum deposits along the south caldera margin, are in the range 21-25 Ma (Table 4, numbers 37-40); these results are approximately concordant with available dates for the host granitic plutons. Slightly older ages for two of the vein biotites, although nearly within analytical uncertainties of ages from the host rock, may hint that the finer-grained biotite of the granitic rock has been slightly reset and that the true emplacement and mineralization ages are 1-2 m.y. older than suggested by determinations on the plutons.

\section{Younger Rift-Related Lavas}

The Amalia Tuff and related rocks of the Latir volcanic field are widely overlain in the Sangre de Cristo Mountains by weakly indurated clastic sedimentary sequences, preserved in downdropped fault blocks and locally containing intercolated lava flows. This dominantly sedimentary sequence consists largely of Precambrian detritus; volcaniclastic debris is conspicuous low in the sequence. The sedimentary rocks locally dip as much as $45^{\circ}$ due to rotation along faults of presumably listric geometry; dips tend to decrease upward in section. The sedimentary sequence is similar to and broadly correlative with Miocene fill deposits of the Rio Grande rift in adjacent areas that have long been included within the Santa $\mathrm{Fe}$ Group. Recognition of Santa Fe Group rocks extending east virtually as far as the boundary between the High Plains and the southern Rocky Mountains indicates that the Miocene rift was much broader, and perhaps different in orientation, in comparison with the present-day structural basin [Lipman, 1981].

In order to further constrain early history of the rift zone, lava flows interlayered with the post-Latir sedimentary sequence were dated in several places. Five silicic-alkalic basalt sequences, which are sufficiently diverse in composition and in geographic position to have required eruption from separate vent areas, have yielded whole rock $\mathrm{K}$-Ar ages of 11-16 Ma (Table 4, numbers 41-45). Four of the ages are clustered at 15-16 Ma, an unexpectedly narrow range, in comparison with the prolonged episodic history of basaltic volcanism (26-2 Ma) in nearby parts of the rift [Lipman and Mehnert, 1975, 1979]. These ages also demonstrate that significant basaltic volcanism occurred along the east side of the Rio Grande rift within a time interval (20-13 Ma) previously believed to have been a lull in rift-related volcanism in New Mexico [Chapin, 1979; Baldridge et al., 1980].

A rhyolitic lava dome, erupted along a major regional riftrelated fault, and in turn displaced several hundred meters along a nearby fault, is the youngest volcanic rock in the Latir Mountains, both from stratigraphic position and its radiometric age of about $12 \mathrm{Ma}$ (Table 4, numbers 46-47). The isotopic results are dispersed for unclear reasons; analysis of a second sample from a different locality failed to produce accordant ages.

Diktytaxitic olivine tholeiite that laps around the northwest margins of the Latir Mountains has been correlated on petrographic and chemical evidence with the Pliocene Servilleta Basalt of the Taos Plateau volcanic field. This correlation is supported by a whole rock K-Ar data of $4.3 \mathrm{Ma}$ on one of these flows, from San Pedro Mesa in southernmost Colorado (Table 4, number 48), an age within the established range for the Servilleta (about 3.6-4.5 Ma [Lipman and Mehnert, 1979]).

\section{Discussion}

Despite interpretative problems with discordances and resetting by successive igneous events, the geochronologic data 


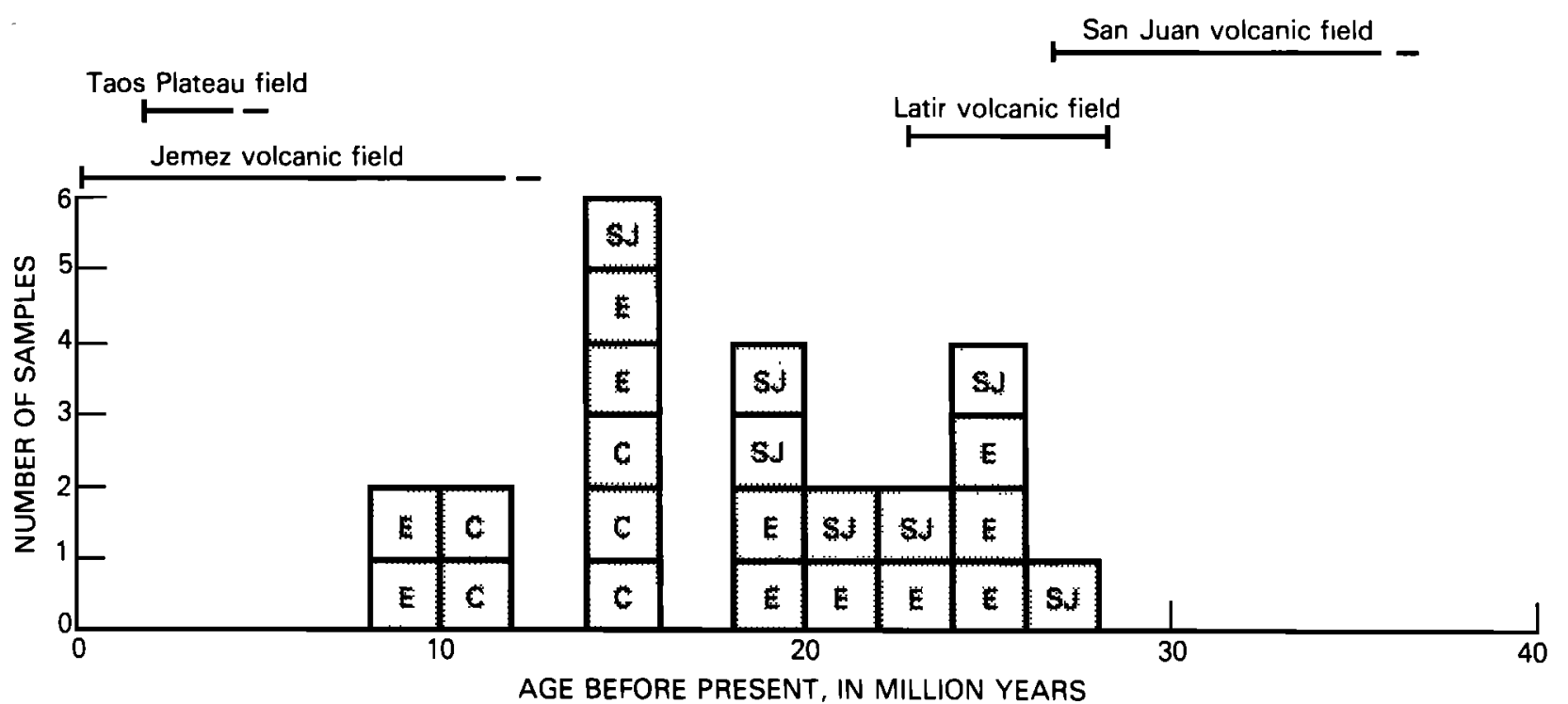

Fig. 4. Histogram of ages of rift-related basalt flows, exposed along margins of southern San Luis Valley and northern Espanola Basin. More silicic rocks of major volcanic fields adjacent to the rift and the Taos Plateau volcanic field (center of rift) are shown by bars, indicating range in age. $C$, Rio Costilla drainage and adjacent parts of northern Latir volcanic field; E, northern Espanola Basin; SJ, eastern San Juan Mountains. Histogram age interval, 2 my. Data are from this paper, Baldridge et al. [1980], Ekas et al. [1984], Lipman and Mehnert [1975], and Manley and Mehnert [1981].

presented here document rapid emplacement and evolution of an upper crustal magmatic system that has regional implications for initiation of rifting in the southern Rocky Mountains in late Oligocene time.

\section{Questa Magmatic System}

Voluminous precaldera lavas and breccias of dominantly intermediate composition, which constitute the bulk of the preserved Latir volcanic field, were erupted mostly within 2 m.y. before eruption of the weakly peralkaline Amalia Tuff and associated caldera collapse at about $26.5 \mathrm{Ma}$ (Figure 3). The clustered precaldera volcanoes near the area of subsequent caldera collapse are interpreted as recording initial accumulation of magma that led to growth and fractionation of a batholithic scale shallow chamber of the Questa magmatic system just prior to eruption of the Amalia Tuff [Lipman, 1983].

The most voluminous granitic rocks, both intracaldera resurgent plutons and the large Rio Hondo batholith south of the caldera, have emplacement and cooling ages of $25-26 \mathrm{Ma}$, only marginally significantly younger than the time of caldera formation. These are thought to represent crystallized upper parts of the magma chamber that underlay the Questa caldera at the time of its formation. Smaller granitic plutons along the south caldera margin, and also the Lucero pluton farther to the south, yield seemingly younger emplacement ages in the range 21-23 $\mathrm{Ma}$, although these must be regarded as minimum ages because of possible resetting related to yet younger Rio Grande rift magmatism and tectonics. These late plutons are associated with the economically important molybdenum mineralization of the region, a relation similar to other caldera-related ore deposits in the southern Rocky Mountains which are consistently associated with postcaldera igneous events [Steven, 1975]. No postcaldera volcanic rocks are preserved within the Latir field, other than much younger riftrelated basaltic flows, but such rocks are preserved on the intrarift horst west of Questa [Thompson and Dungan, 1984]. Intermediate to silicic volcanism as young as $22-23 \mathrm{Ma}$, that probably represents late volcanism of the Questa magmatic system, is also demonstrated by dated volcanic clasts in rift fill sediments [Ekas et al., 1984].

\section{Rift Volcanism}

The early volcanic history of the Rio Grande rift in northern New Mexico and southern Colorado, subsequent to waning of volcanism in the Questa-Latir area at about $22 \mathrm{Ma}$, is poorly constrained, largely because deeper parts of the rift zone are covered by thick fill. Recent publications about the rift have inferred a gap in mafic magmatic activity between about 10 and $20 \mathrm{Ma}$ [Chapin, 1979; Baldridge et al., 1981, 1984; Seager et al., 1984], based largely on relations determined in the southern rift. Little support for such a "magma gap" is evident, however, if one evaluates the chronology of mafic rift volcanics interbedded with Miocene strata exposed along margins of the rift (Figure 4); any volcanic rocks of this age along the axial regions of the present rift are still largely buried. Data are still relatively sparse, but ages of basaltic rocks in the southern San Luis Valley (eastern San Juan Mountains), Questa-Latir area (Costilla drainage), and Espanola Basin north of the Jemez field are as abundant in the interval $10-20 \mathrm{Ma}$ as for preceding and following time intervals. The northern New Mexico-southern Colorado sector of the rift, roughly where intersected by the diffuse Jemez magmatic zone (Figure 1), was the locus of especially intense early rift volcanism in the Latir field and similarly intense late rift activity in the Jemez and Taos Plateau volcanic fields. This sector appears also to have been a locus of basaltic volcanism in mid Miocene, when the southern rift lacked significant volcanism.

\section{Geochronologic Problems}

A major result of the present study, in addition to documenting the chronologic evolution of the Questa magmatic system, is demonstration of the complex thermal behavior of minerals that are commonly utilized for K-Ar and F-T dating, especially in deep parts of a volcanic field adjacent to a complex shallow magma chamber. Because the total age span for the main phase of the Questa magmatic system was only a few 

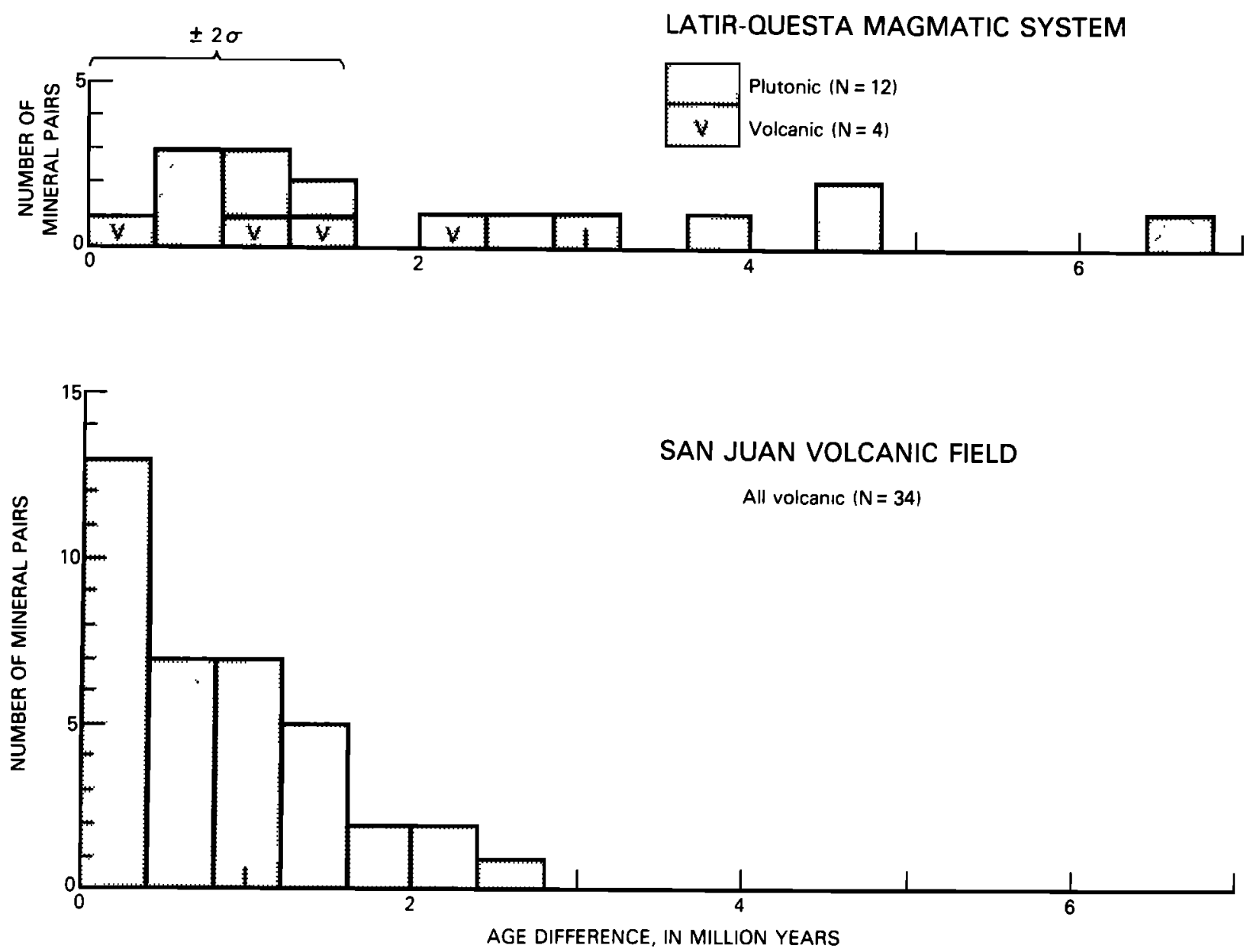

Fig. 5. Comparisons of degree of discordance among multiple K-Ar ages, analyzed minerai pairs from individual samples: Latir-Questa magmatic system (this paper) and San Juan volcanic field [Lipman et al., 1970; Hon and Mehnert, 1983]. N, number of samples.

million years, about $28.5-25.0 \mathrm{Ma}$, interpretive problems due to the thermal resetting of earlier igneous events by later ones are significant. Many results for multiple mineral phases from single samples are discordant beyond analytical uncertainties, and interpretations are accordingly uncertain.

An instructive comparison is with $\mathrm{K}$-Ar dates for rocks of similar age from the San Juan volcanic field of southwestern Colorado; both studies involved comparable field and laboratory techniques (Figure 5). In samples of the San Juan field, about $85 \%$ of the mineral pairs are concordant within estimated analytical uncertainty (typical 2 s.d., \pm 0.8 m.y.). In contrast for the Latir field, about half the samples, especially the plutonic rocks, are discordant, beyond analytical uncertainty.

In the Latir field, the F-T zircon results are even more discordant than the K-Ar results, as indicated by comparison of both types of data with the best interpreted emplacement ages based on combined data from the entire sample suite (Figure 6). K-Ar biotite ages are more variable than sanidines and tend to be younger, especially for the granitic rocks; F-T zircon results are systematically younger for all but a few samples collected at greatest distances from the center of the volcanic field. These results indicate that thermal blocking temperatures for argon retention were slightly higher in the sanidine than for biotite, and that both retain argon at temperatures conducive for annealing of fission tracks in zircon.
This pattern of discordant ages in the Questa data is consistent with the sequence of ages observed in other studies where there has been slow cooling or a later thermal event [Wagner et al., 1977; Harrison et al., 1979; Naeser, 1979]. That is, biotite (K-Ar) is older than zircon (F-T) which is older than apatite (F-T). The "blocking temperatures" for these minerals over geologically significant intervals (about $10^{6} \mathrm{~m} . \mathrm{y}$.) are biotite $\sim 300^{\circ} \mathrm{C}$ [Jager, 1979], zircon $\sim 230^{\circ} \mathrm{C}$ [Hurford, 1984], and apatite $\sim 120^{\circ} \mathrm{C}[$ Naeser, 1981].

The thermal effects of the younger intrusions, although significantly affecting the K-Ar and F-T systematics, seemingly had much less effect on the light-stable isotopic chemistry (oxygen, hydrogen) or on paleomagnetic properties of the granitic rocks [Hagstrum and Johnson, 1984]. Both kinds of data indicate that a large geothermal system was associated with the Questa magnatic system, especially in and adjacent to the Rio Hondo pluton. Activity of the geothermal system is interpreted to have peaked during primary cooling of the Rio Hondo body at about $25.5 \mathrm{Ma}$, with only minor magnetic and stable isotopic effects superimposed from the smaller younger plutons to the north and south.

Refinement of the geochronology for the Questa magmatic system will require application of additional geochronologic techniques, in conjunction with other methods to appraise the nature of the pluton-related alteration and metamorphism such as the paleomagnetic and stable isotope approaches just 


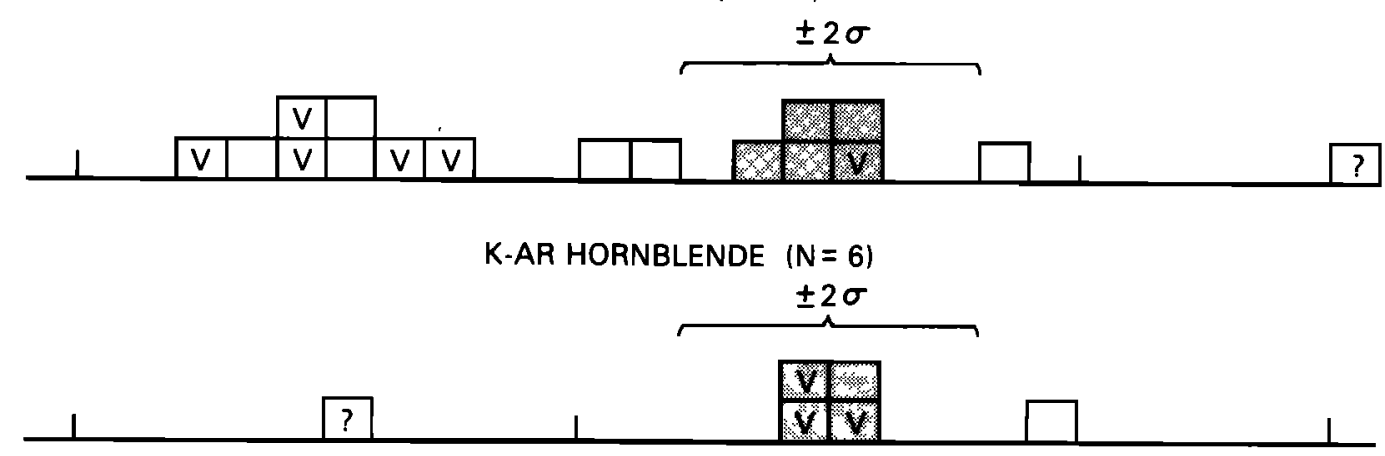

K-AR BIOTITE ( $N=23)$

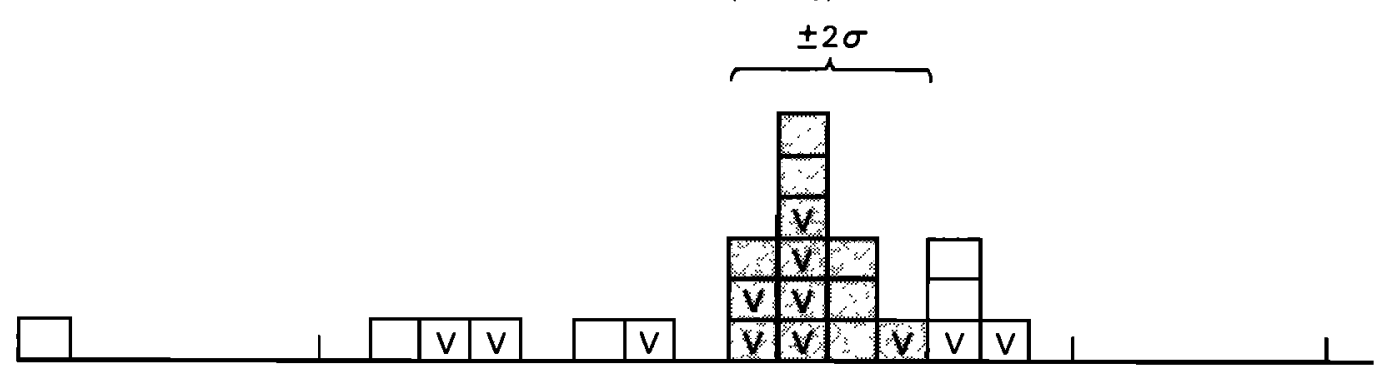

K-AR SANIDINE $(\mathrm{N}=24)$

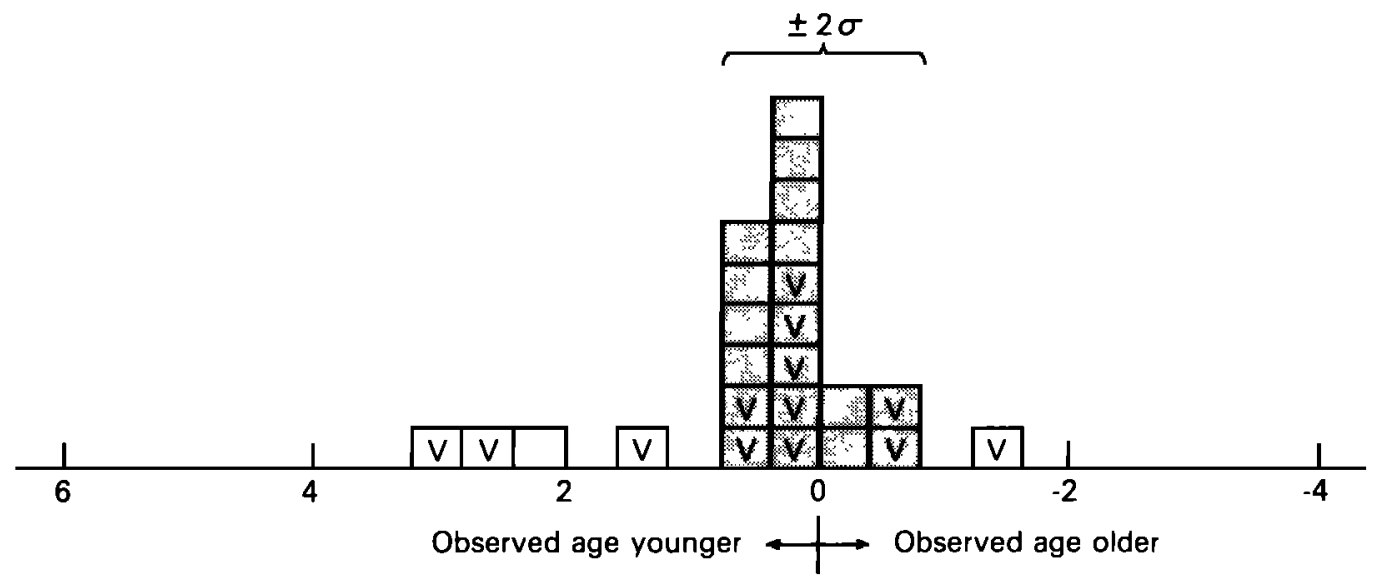

INTERPRETED AGE MINUS OBSERVED AGE, IN MILLION YEARS

Fig. 6. Differences, in millıon years, between interpreted age versus observed $\mathrm{K}$-Ar sanidine, biotite, and hornblende dates, and F-T zircon dates for the same sample (Data from Tables 1 and 2). Boxes marked by " $v$ " are data from volcanic rocks; empty boxes represent data from intrusive rocks. Shaded values are within 2 s.d. of interpreted ages. Queried values are of doubtful significance because reanalysis of a second sample from the same site yielded more nearly concordant results. $N$, number of samples.

noted. Additional $\mathrm{Rb}-\mathrm{Sr}$ mineral and rock isochron determinations are needed, especially for the granitic rocks, and ${ }^{40} \mathrm{Ar} /{ }^{39} \mathrm{Ar}$ dating techniques would seem promising to see through thermal overprinting to resolve the timing of emplacement events.

\section{Cooling and Uplift Rates}

The zircon (and also the few apatite) F-T results are especially useful as indicators of thermal history of the QuestaLatir area, including cooling of the subvolcanic batholith and subsequent uplift rates for the Sangre de Cristo Mountains during growth of the Rio Grande rift. The near concordance of zircon F-T and feldspar K-Ar ages for samples from the intracaldera intrusions is in striking contrast to the younger zircon ages obtained from the penecontemporaneous Rio Hondo batholith to the south of the caldera. This contrast in cooling ages is interpreted as recording different levels of emplacement and rates of cooling, becoming deeper and slower to the south in accord with the stratigraphic and structural evidence of increased subsequent uplift to the south.

The contrast is even more striking for the sparse apatite F-T data: the one apatite date for the northern intracaldera intrusions is essentially concordant with zircon ages, but apatite ages are 4-9 m.y. younger than the zircon ages in the Rio Hondo batholith and Lucero Peak pluton. These results support the interpretation based on structural data that the intra- 
caldera plutons, though now exposed at about the same topographic elevation as the southern intrusions (Rio Hondo, Lucero), were shallower at time of emplacement and accordingly cooled more rapidly. The apatite age for the Cabresto Lake pluton, within the caldera, is within analytical uncertainty of its interpreted emplacement age, indicating cooling to the $100^{\circ} \mathrm{C}$ isotherm (the equilibrium annealing temperature for fission tracks in apatite) within a million years or so of intrusion. Detailed interpretation of the cooling history of these plutons is complicated by their variable compositions (granite to quartz monzonite), which probably reflect somewhat differing emplacement temperatures, and uncertainties about the thermal mass of differing parts of the plutonic system. All the exposed plutons are inferred to represent cupolas over a composite batholith at only slight greater depth, and thus the exposed size of the various plutons may not validly reflect their thermal mass.

Regional uplift rates for the Sangre de Cristo Mountains and nearby mountains along the northern Rio Grande rift have been inferred to be about $200 \mathrm{~m} / \mathrm{my}$, largely from analysis of apatite F-T cooling ages of Precambrian and Tertiary rocks in the Taos area including the apatite data of this report [Kelley and Duncan, 1984]. These rates, in conjunction with the differences between F-T apatite ages and interpreted emplacement ages for the Lucero and Rio Hondo plutons, could suggest that the southern intrusions were emplaced $1.4-2.8 \mathrm{~km}$ (Rio Hondo) deeper than the intracaldera intrusions. Note, however, that interpretation of thermal gradients in roof zones of cooling plutons cannot be directly compared to estimates based on inferred regional thermal gradients.

\section{Regional Tectonic Implications}

Available evidence, both from rock distributions and isotopic ages, indicates that the bulk of the volume of the Questa magmatic system was emplaced within 2-3 m.y., during initiation of extension along the Rio Grande rift in the late Oligocene (Figure 3). The beginning of rift-related extension in the Latir-Questa area at about $26 \mathrm{Ma}$ is documented by emplacement of quartz latitic and granitic intrusions along riftrelated normal faults, by oversteepening and rheomorphic flow of the Amalia Tuff along such faults, and by interactions between structures of the Questa caldera and regional structural trends [Lipman, 1983]. Although early southwest directed extension along the Rio Grande rift zone was thus underway during the culmination of activity in the Latir volcanic field, the rift was a sufficiently shallow broad feature that ash flows from the Questa caldera were able to spread across it westward to the Tusas Mountains. On a more regional scale, initial extension within the rift area is documented by inception of basin fill deposition and associated eruption of basaltic lava flows at about $26 \mathrm{Ma}$, both in the San Luis Valley segment of the rift north of Questa [Lipman and Mehnert, 1975] and in the Albuquerque-Socorro Basin to the south [Chapin, 1979].

The Latir volcanic field is the largest and most compositionally diverse igneous area that was active during the early development of the Rio Grande rift in northern New Mexico and southern Colorado. Broadly similar ash flow fields farther north in Colorado are older and increase in age northward (Figure 3). Peak silicic volcanism and caldera formation in the San Juan field was 27-31 $\mathrm{Ma}$, following precaldera intermediate-composition eruptions extending back at least to 35-36 Ma [Lipman et al., 1970; Hon and Mehnert, 1983]. Similar centers in the Sawatch Range and Thirtynine Mile volcanic areas farther north in Colorado, including the Bon- anza center that provides a bridge with the San Juan calderas [Varga and Smith, 1984], had caldera-related ash flow eruptions at about 34-36 Ma; some granitic intrusive rock such as the Mount Princeton batholith appear to be as old as $40 \mathrm{Ma}$ [Simmons and Hedge, 1978]. If one crosses the nonmagnetic area of southern Wyoming, the peak of Tertiary volcanism in the northern Rocky Mountains is even older, 55-45 Ma, in the Absaroka, Challis, and Lowland Creek volcanic fields [Lipman, 1981].

In contrast, to the south of the Latir field, a nearly complete magmatic gap, especially for silicic volcanism, existed in the mid-Tertiary, for $250 \mathrm{~km}$ to the northeast margin of the Mogollon-Datil field. The only exceptions are volumetrically small intermediate-composition centers in the Ortiz Mountains between Santa $\mathrm{Fe}$ and Albuquerque (Figure 1 [Kautz et al., 1981]). These age distribution relations document a crude migration of silicic igneous activity southward through the Rocky Mountains, prior to initiation of the Rio Grande rift. The southward migration, which constitutes only one component of the complex pattern of evolution in igneous geometry in the western United States [Coney and Reynolds, 1977; Lipman, 1981]), may have been a critical precursor in heating and weakening the lithosphere that helped localize initial rifting in the eastern Cordilleran region.

Acknowledgments. Study of the Questa area was initiated as part of research on the internal structures of ash flow caldera and their relation to fossil geothermal systems, supported by the Geothermal Research Program of the U.S. Geological Survey (USGS). Parts of the study have also been supported by the USGS's Wilderness Program. Our work has benefited greatly from cooperation with personnel of the Questa Division of Union Molycorp, as well as with staff of Carson National Forest, the Rio Costilla Cooperative Livestock Association, and the Vermejo Park Corporation. In addition, we are grateful to our USGS colleagues, Lin Cordell, Gerry Czamanske, John Hagstrum, Clark Johnson, Steve Ludington, Jack Reed, and Ren Thompson, who have shared unpublished data on important aspects of the geology, geochemistry, and geophysics of the Questa area. Sample preparation and mineral separations for radiometric dating were done by Gerald Cebulla, Jack Groen, and Donald Cheney. Two previously unpublished F-T ages were provided by Patty Billings of the USGS. We thank John Obradovich and Robert Scott for reviewing earlier versions of this paper.

\section{REFERENCES}

Baldridge, W. S., P. E. Damon, M. Shafiqullah, and R. J. Bridwell, Evolution of the central Rio Grande rift, New Mexico: new potassium-argon ages, Earth Planet. Sci. Lett., 51, 309-321, 1980.

Baldridge, W. S., K. H. Olson, and J. F. Callender, Rio Grande rift: Problems and perspectives, Field Conf. Guideb. N. M. Geol. Soc., 35 1-12, 1984.

Bingler, E. C., Geology and mineral resources of Rio Arriba County, New Mexico, Bull. N. M. Bur. Mines Miner. Resour., 45, 104 pp., 1968.

Butler, A. P., Jr., Tertiary volcanic stratigraphy of the eastern Tusas Mountains, southwest of the San Luis Valley, Colorado-New Mexico, Field Conf. Guideb. N. M. Geol. Soc., 22, 289-300, 1971.

Chapin, C. E., Evolution of the Rio Grande rift-A summary, in Rio Grand Rift: Tectonics and Magmatism, edited by R. E. Riecker, pp. 1-5, AGU, Washington, D. C., 1979.

Clark, K. F., and C. B. Read, Geology and ore deposits of the Eagle Nest area, New Mexico, Bull. N. M. Bur. Mines Miner. Res., 94, 152 pp., 1972.

Coney, P. J., and S. J. Reynolds, Cordilleran Benioff zones, Nature, 270, 403-406, 1977.

Dungan, M. A., W. R. Muehlberger, L. Leininger, C. Peterson, N. J. McMillan, G. Gunn, M. Lindstrom, and L. Haskin, Volcanic and sedimentary structure of the Rio Grande gorge and the late Cenozoic geologic evolution of the southern San Luis Valley, Field Conf. Guideb. N. M. Geol. Soc., 35, 157-170, 1984.

Ekas, L. M., R. V. Ingersoll, W. S. Baldridge, and M. Shafiqullah, The Chama-el Rito Member of the Tesuque Formation, Espanola Basin, New Mexico, Field Conf. Guideb. N. M. Geol. Soc., 35, 137$143,1984$. 
EJston, W. E., and T. J. Bornhorst, The Rio Grande rift in context of regional post $40 \mathrm{~m}$.y. volcanic and tectonic events, in Rio Grande rift: tectonics and magmatism, edited by $R$. E. Riecker, pp. 416-438, AGU, Washington, D. C., 1979.

Epis, R. C., and C. E. Chapin, Geologic history of the Thirtynine Mile volcanic field, central Colorado, Cenozic Volcanism in the Southern Rocky Mountains, edited by R. C. Epis, Colo. Sch. Mines Q., 63, 51-86, 1968.

Hagstrum, J. T., and C. M. Johnson, A paleomagnetic and isotopic study of chemical remanent magnetization associated with hydrothermal alteration in the pluton of Rio Hondo, near Questa, New Mexico, Ph.D. thesis, part II, 41 pp., Stanford Univ., Stanford, Calil., 1984.

Hagstrum, J. T., and P. W. Lipman, Paleomagnetism of the structurally deformed Latir volcanic field, northern New Mexico: Relations to formation of the Questa caldera and development of the Rio Grande rift, Ph.D. thesis, part I, 43 pp., Stanford Univ., Stanford, Calif., 1984.

Hagstrum, J. T., P. W. Lipman, and D. P. Elston, Paleomagnetic evidence bearing on the structural development of the Latir volcanic field near Questa, New Mexico, J. Geophys. Res., 87, 7833$7842,1982$.

Harrison, T. M., R. L. Armstrong, C. W. Naeser, and J. E. Haraka, Geochronology and thermal history of the Coast Plutonic Complex, near Prince Rupert, British Columbia, Can. J. Earth Sci., 16, $400-410,1979$.

Hon, K., and H. H. Mehnert, Compilation of revised ages of volcanic units in the San Juan Mountains, Corado: Recalculated K-Ar age determinations using IUGS constants, U.S. Geol. Surv. Open File Rep., 83-668, 14 pp., 1983.

Hurford, A. J., On the closure temperature for fission tracks in zircon, paper presented at the 4th International Fission Track Dating Workshop, Rensselaer Polytechnic Inst., Troy, N. Y., 22, 1984.

Jager, E., Introduction to geochronology, in Lectures in Isotope Geology, edited by E. Jager and J. C. Hunziker, pp. 1-12, SpringerVerlag, New York, 1979.

Jones, D. M., and J. R. Norris, Geology of the South Fork molybdenum occurrance, Taos County, New Mexico, Field Conf. Guideb. N. M. Geol. Soc., 35, 213-218, 1984.

Kautz, P. F., R. V. Ingersoll, W. S. Baldridge, P. E. Damon, and M. Shafiqullah, Geology of the Espinaso Formation (Oligocene), north-central New Mexico: Summary, Geol. Soc. Am. Bull., 92, 980983, 1981.

Kelley, S. A., and I. J. Duncan, Tectonic history of the northern Rio Grande rift derived from apatie fission-track geochronology, Field Conf. Guideb. N. M. Geol. Soc., 35, 67-74, 1984.

Laughlin, A. W., W. A. Rehrig, and R. L. Mauger, K-Ar chronology and sulfur and strontium isotope ratios at the Questa mine, New Mexico, Econ. Geol., 64, 903-909, 1969.

Leonardson, R., W. G. Dunlap, V. L. Starquist, G. P. Bratton, J. W. Meyer, L. W. Osborn, S. A. Atkin, P. A. Molling, R. F. Moore, and S. D. Olmore, Preliminary geology and molybdenum deposits at Questa, New Mexico, in The genesis of Rocky Mountain ore deposits: changes with time and tectonics, in Proceedings of a Symposium, pp. 151-155, Denver Region Exploration Geologists Society, Denver, Colo., 1983.

Lipman, P. W., Volcano-tectonic seeting of Tertiary ore deposits in the southern Rocky Mountains, Relation of Tectonics to Ore Deposits in the Southern Cordillera, edited by W. R. Dickinson and W. D. Payne, Ariz. Geol. Soc. Dig., 14, 199-211, 1981.

Lipman, P. W., The Miocene Questa caldera, northern New Mexico: Relation to batholith emplacement and associated molybdenum mineralization, in The genesis of Rocky Mountain ore deposits: changes with time and tectonics, in Proceedings of a Symposium, pp. 133-147, Denver Region Exploration Geologists Society, Denver, Colo., 1983.

Lipman, P. W., and H. H. Mehnert, Late Cenozoic basaltic volcanism and development of the Rio Grande depression in the southern Rocky Mountains, Geologic History of the Southern Rocky Mountains, edited by B. F. Curtis, Mem. Geol. Soc. Am., 144, 119-154, 1975.

Lipman, P. W., and H. H. Mehnert, The Taos Plateau volcanic field, northern Rio Grande rift, New Mexico, in Rio Grande Rift: Tec- tonics and Magmatism, edited by R. C. Riecker, pp. 289-311, AGU, Washington, D. C., 1979.

Lipman, P. W., T. A. Steven, and H. H. Mehnert, Volcanic history of the San Juan Mountains, Colorado, as indicated by potassiumargon dating, Geol. Soc. Am. Bull., 81, 2329-2352, 1970.

Lucas, S. G., Correlation of Eocene rocks of the northern Rio Grande rift and adjacent areas: Implications for Laramide tectonics, Field Conf. Guideb. N. M. Geol. Soc., 35, 123-128, 1984.

Ludington, S., Quartz-purite-molybdenite stockwork near South Fork Peak, Taos County, New Mexico, U.S. Geol. Surv. Open File Rep., 81-180, 8 pp., 1981.

Manley, K., Redefinition and description of the Los Pinos Formation of north-central New Mexico, Geol. Soc. Am. Bull., 92, 984-989, 1981.

Manley, K., and H. H. Mehnert, New K-Ar ages for Miocene and Pliocene volcanic rocks in the northwestern Espanola Basin and their relationships to the history of the Rio Grande rift, Isochron West, 30, 5-8, 1981 .

Naeser, C. W., The use of apatite and sphene for fission track age determinations, Geol. Soc. Am. Bull., 78, 1523-1526, 1967.

Naeser, C. W., Fission-track dating and geologic annealing of fission tracks, Lectures in Isotope Geology, edited by E. Jager and J. C. Hunziker, pp. 154-169, Springer-Verlag, New York, 1979.

Naeser, C. W., The fading of fission tracks in the geologic environment-Data from deep drill holes, Nucl. Tracks, 5, 248-250, 1981.

Pillmore, C. L., J. D. Obradovich, J. O. Landreth, and L. E. Pugh, Mid-Tertiary volcanism in the Sangre de Cristo Mountains of northern New Mexico, Geol. Soc. Am. Abstr. Programs, 5, 502, 1973.

Reed, J. C., Jr., P. W. Lipman, and J. M. Robertson, Geologic map of the Latir Peak and Wheeler Peak wildernesses and ColumbineHondo wilderness study area, Taos County, New Mexico, U.S. Geol. Surv. Misc. Field Invest. Map, MF-1750-B, 1983.

Seager, W. R., M. Shafiqullah, J. W. Hawley, and R. F. Marvin, New dates from basalts and the evolution of the southern Rio Grande rift, Geol. Soc. Am. Bull., 95, 87-99, 1984.

Shassberger, H. T., K-Ar ages on intrusive rocks and alteration associated with molybdenum mineralization at Climax and Urad, Colorado, and Questa, New Mexico, Isochron West, 2, 29, 1972.

Shibata, K., and S. Ishihara, K-Ar ages on biotite from Questa mine area, New Mexico, USA, Bull. Geol. Surv. Jpn., 19, 35-38, 1968.

Simmons, E. C., and C. E. Hedge, Minor-element and Sr-isotope geochemistry of Tertiary stocks, Colorado mineral belt, Contrib. Mineral. Petrol., 67, 379-396, 1978.

Steiger, R. H., and E. Jager, Subcommission on geochronology: conventions on the use of decay constants in geo- and cosmochronology, Earth Planet. Sci. Lett., 36, 359-362, 1977.

Steven, T. A., Middle Tertiary volcanic field in the southern Rocky Mountains, Cenozoic History of the Southern Rocky Mountains, edited by B. F. Curtis, Mem. Geol. Soc. Am., 144, 75-94, 1975.

Thompson, R. A., and M. A. Dungan, Multiple fractionation processes in early rift volcanics: northern Rio Grande rift, New Mexico, in Proceedings of the ISEM Confernce on Open Magmatic Systems, pp. 154-156, Institute for the Study of the Earth and Man, Dallas, Tex., 1984.

Varga, R. J., and B. M. Smith, Evolution of the early Oligocene Bonanza caldera, northeast San Juan volcanic field, Colorado, J. Geophys. Res., 89, 8679-8694, 1984.

Wagner, G. A., G. M. Reimer, and E. Jager, Cooling ages derived by apatite fission-track, mica $\mathrm{Rb}-\mathrm{Sr}$, and $\mathrm{K}-\mathrm{Ar}$ dating: The uplift and cooling history of the Central Alps, memoir, 28 pp., Instit. of Geol. and Mineral., Univ. of Padova, Padua, Italy, 1977.

P. W. Lipman, H. H. Mehnert, and C. W. Naeser, U.S. Geological Survey, Box 25046, MS/913, Denver Federal Center, Denver, CO 80225.

(Received January 24, 1985; revised June 28, 1985; accepted July 1, 1985.) 